Author version: Sedimentology, vol.58(3); 2011; 756-784

\title{
Bacterial response to contrasting sediment geochemistry in Central Indian Basin
}

\author{
ANINDITA DAS, CHRISTABELLE E. G. FERNANDES, SONALI S. NAIK, B. NAGENDER NATH, \\ I. SURESH, M.B.L. MASCARENHAS-PEREIRA, S.M. GUPTA, N.H. KHADGE, \\ C. PRAKASH BABU, D.V. BOROLE, SUJITH, P.P., A. B. VALSANGKAR, B. SHASHIKANT MAURYA, \\ SUSHANTA U. BICHE, R. SHARMA and P. A. LOKA BHARATHI* \\ National Institute of Oceanography, Dona Paula, Goa-403004, India \\ *Corresponding author: loka@nio.org. \\ Ph: 091-0832-2450281 \\ Fax: 091-0832-2450606
}

\section{ABSTRACT}

In order to investigate whether geochemical, physiographic and lithological differences in two end-member sedimentary settings could evoke varied microbe-sediment interactions, two $25 \mathrm{~cm}$ long sediment cores from contrasting regions in the Central Indian Basin have been examined. Site TVBC 26 in the northern siliceous realm $\left(10^{\circ} \mathrm{S}, 75.5^{\circ} \mathrm{E}\right)$ is organic-C rich with $0.3 \pm 0.09 \%$ total organic carbon. Site TVBC 08 in the southern pelagic red clay realm $\left(16^{\circ} \mathrm{S}, 75.5^{\circ} \mathrm{E}\right)$, located on the flank of a seamount in a mid-plate volcanic area with hydrothermal alterations of recent origin, is organic-C poor $(0.1 \pm 0.07 \%)$. Significantly higher bacterial viability under anaerobic conditions, generally lower microbial carbon uptake and higher numbers of aerobic sulphur oxidizers at the mottled zones characterize core TVBC 26. In the carbon-poor environment of core TVBC 08, a doubling of the ${ }^{14} \mathrm{C}$ uptake, a 250 times increase in the number of autotrophic nitrifiers, a fourfold lowering in the number of aerobic sulphur oxidizers and an order higher of denitrifiers exist when compared to core TVBC 26. This suggests the prevalence of a potentially autotrophic microbial community in core TVBC 08 in response to hydrothermal activity. Microbial activity at the northern TVBC 26 is predominantly heterotrophic with enhanced chemosynthetic activity restricted to tangreen mottled zones. The southern TVBC 08 is autotrophic with increased heterotrophic activity in the deepest layers. Notably, the bacterial activity is generally dependent on the surface productivity in TVBC 26, the carbon-rich core, and mostly independent in TVBC 08, the carbon-poor, hydrothermally influenced core. The northern sediment is more organic sink-controlled and the southern more hydrothermal source-controlled. Hydrothermal activity and associated rock alteration processes may be more relevant than organic matter delivery in these deep-sea sediments. Thus, this study highlights the relative importance of hydrothermal activity versus organic delivery in evoking different microbial response in the Central Indian Basin sediments.

Keywords Autotrophy, bacteria, Central Indian Basin, diagenesis, hydrothermal, non-steady state, numerical simulation, sediment, transition zone 


\section{INTRODUCTION}

The deep-sea floor is predominantly a microbial habitat with a relatively low input $(0.01$ to $1 \%$ ) of photosynthetically produced organic matter (Suess et al., 1980). The average temperature and pressure generally remain around $2^{\circ} \mathrm{C}$ and 500 bars respectively in these sediments. However, the more subtle differences in organic matter, porewater and sediment geochemistry dictate variations among the local communities of microorganisms in terms of numbers and activity. The role played by the number of microorganisms in terms of total counts and relative abundance is gaining importance. Recent microbiological studies on the Namibian Shelf (GeoB cores) and Eastern Equatorial Pacific (ODP Leg 201) show that culturable bacteria are constant in abundance over large stretches of the ocean. Cultured bacteria vary consistently from one sub-sea floor environment to another and have been shown to contribute significantly to important biogeochemical processes (D'Hondt et al., 2004).

The abundance and activity of culturable bacteria are directly linked to mineralization processes (Schultz \& Schultz, 2005) adapted to very low metabolic rates (Teske et al., 2004). These mineralization processes are dependent on organic matter diagenesis and hydrothermal fluid interactions (Ma et al., 2006). Hydrothermal fluids from magmatic hotspots, faults and fractures are spread over large stretches of the ocean basin (D'Hondt et al., 2002, 2004). These fluid interferences link the nutrient and the rock cycle providing a wide array of electron donors and acceptors for microbial proliferation and activity, including chemosynthesis. Co-occurrence of multiple metabolic pathways (Wang et al., 2008) or overlap of multiple metabolic zones (Canfield \& Thamdrup, 2009) emphasizes the extensive chemosynthetic potential of bacteria.

The aim of this paper is to investigate how geochemical, physiographic and lithological differences in two end-member sedimentary settings evoke different microbe-sediment interactions. To address this objective two geochemically and sedimentologically contrasting cores of the Central Indian Basin (CIB; Fig. 1A and B) were examined for distinctions between microbial communities and the extent of chemoautotrophy. Modern microbial and biochemical processes along with the porewater geochemistry and porosity have been integrated with stratigraphic data in order to understand and quantify the factors determining the extent of chemosynthetic potential in these two end-member sedimentary settings in the CIB.

\section{GEOLOGICAL SETTING OF THE CENTRAL INDIAN BASIN}

The CIB, with an area of $5.7 \times 10^{6} \mathrm{~km}^{2}$ (Ghosh \& Mukhopadhyay, 1999), has five sediment types namely, terrigenous mud, siliceous ooze with and without nodules, pelagic red clays and 
carbonaceous ooze (Fig. 1A; Nath et al., 1989; Rao \& Nath, 1988). The basin is bordered by the Indian Ocean Ridge system and marked by prominent fracture zones (FZ) and seamounts hosting normal-Mid Ocean Ridge Basalts (Fig. 1B; Kamesh Raju \& Ramprasad, 1989; Mukhopadhyay et al., 2002; Das et al., 2007).

The oxygen and nutrient-rich Antarctic Bottom Water Current (AABW) entering the CIB from $5^{\circ} \mathrm{S}$ (Gupta \& Jauhari, 1994) maintained oxic conditions during the past ca $1100 \mathrm{kyr}$ (Pattan et al., 2005). Terrigenous influx decreases from north to south (Rao \& Nath, 1988; Nath et al., 1989). Higher surface productivity, and therefore higher detrital rain from overlying surface waters (Matondkar et al., 2005), make the organic matter supply to the siliceous ooze higher than the red clays (Gupta \& Jauhari, 1994). Other factors influencing distribution of organic carbon are sedimentation rates, bottom water oxygenation, water depth, topography, bioturbation, recalcitrance and age (Lyle et al., 1983; Nath et al., 1997; Lochte et al., 1999). The two stations studied here are located along transect $75.5^{\circ} \mathrm{E}$, in close proximity to the Trace of Rodriguez Triple Junction.

\section{Geological features of northern siliceous oozes}

The sea-floor spreading rate at this location is fast at $90 \mathrm{~mm} \mathrm{kyr}^{-1}$ (Mukhopadhyay et al., 2002). Temperature and dissolved oxygen of bottom water is 0.9 to $1.03^{\circ} \mathrm{C}$ and 4.2 to $4.3 \mathrm{ml}^{-1}$ respectively (Warren et al., 1982; Nath et al., 1992). Surface C/N ratios of this TOC- rich core range from 3 to 6 (Gupta \& Jauhari, 1994; Pattan et al., 2005). Illite is the dominant clay type with a $\mathrm{SiO}_{2} / \mathrm{Al}_{2} \mathrm{O}_{3}$ ratio of 6.7 and biogenic silica varies from 10 to $35 \%$. Early diagenetic processes are attributed to the formation of rough nodules when the $\mathrm{Mn} / \mathrm{Fe}$ ratio $>1$, with higher $\mathrm{Mn}, \mathrm{Cu}$, $\mathrm{Ni}$ and todorokite mineralogy (Rao \& Nath, 1988; Nath et al., 1989).

\section{Geological features of southern pelagic red clay}

The sea-floor spreading rate is slow at $26 \mathrm{~mm} \mathrm{kyr}^{-1}$ (Mukhopadhyay et al., 2002). Temperature and dissolved oxygen of bottom waters are $>1.03^{\circ} \mathrm{C}$ and 4.1 to $4.2 \mathrm{ml}^{-1}$ respectively (Warren et al., 1982; Nath et al., 1992). The surface $\mathrm{C} / \mathrm{N}$ ratio of this total organic carbon (TOC)poor core ranges from 3 to 6 (Gupta \& Jauhari, 1994). The dominant clay type is montmorillonite with a $\mathrm{SiO}_{2} / \mathrm{Al}_{2} \mathrm{O}_{3}$ ratio of 4.5 and biogenic silica amounting to 5 to $10 \%$. The $\mathrm{Mn} / \mathrm{Fe}$ ratio is $<1$ suggesting hydrogenetic metal precipitation (Rao \& Nath, 1988; Nath et al., 1989). The nature of the glass shards (Mascarenhas-Pereira et al., 2006), native aluminium content (Iyer et al., 2007) and signatures of degassing (Nath et al., 2008) suggest hydrothermal alteration of recent origin in some locations. Late Tertiary sediments are probably exposed in this area due to explosive volcanism (Mascarenhas-Pereira et al., 2006). 


\section{GEOMICROBIOLOGY OF THE CENTRAL INDIAN BASIN}

\section{Northern siliceous ooze}

The northern siliceous setting is rich in TOC with a concentration $c a 0.3 \%$. Early diagenetic processes and extensive nitrification in this region influence the origin, type and quality of manganese nodules (Nath \& Mudholkar, 1989) and sediment biogeochemistry as a whole. The microbial community might co-express both chemolithotrophy and organotrophy. This would enable efficient recycling of the limited photosynthetically derived organic matter (Stevens, 1997; Ehrlich, 1998). Cultured bacterial representatives showing both phases of nitrification have been isolated from this region (Ram et al., 2001). Microbial processes like manganese oxidation (Ehrlich, 1998 \& references therein) and manganese cycling in tan-green mottled zones (Meister et al., 2009) possibly co-occur (Wang et al., 2008) along with the coupling of nitrification-denitrification (Luther III et al., 1997). Similarly, sulphide oxidation and iron reduction could co-occur. Here, the mixotrophic combination of chemolithotrophy and organotrophy might be due to simultaneous dependence on the supply of organic matter and possible rock alteration features. The setting might be analogous to that of the hydrocarbon deposits except for the scale and extent (Canfield, 1991; Ma et al., 2006; Campbell, 2006).

\section{Southern pelagic red clay}

The southern pelagic red clay setting is TOC-poor with a concentration of $<0.1 \%$. It bears the signature of recent hydrothermal alteration due to tectonic reactivation of fracture zones (Mascarenhas-Pereira et al., 2006; Iyer et al., 2007; Nath et al., 2008). Microbiologically, the southern part of the CIB is largely unexplored. It is therefore hypothesized that chemolithotrophy, though widespread, would be more pronounced in the oligotrophic southern CIB than in the detritally dominated northern region. Proximity to tectonic features such as the Trace of Rodrigues Triple Junction (Kamesh Raju \& Ramprasad, 1989) may indicate sulphide oxidation with iron reduction (Bach \& Edwards, 2003). Thiotrophic nitrate reduction may also be an important contributing process especially in diffuse flow regimes (Childress et al., 1991) with temperatures varying between 2 to $25^{\circ} \mathrm{C}$ (Chevaldonne et al., 1991). The chemoautotrophy might be totally independent of organic matter rain and this system could be analogous to settings like the Loihi Seamount (Edwards et al., 2004). 


\section{MATERIALS AND METHODS}

\section{Sampling area and method}

The samples for the present study were collected and processed during cruises on-board R.V. Akademik Alexandr Siderenko (AAS), and R.V. Akademik Boris Petrov (ABP) as a part of the PMNEIA (Polymetallic Nodules-Environmental Impact Assessment) programme in the CIB. Two endmember settings, represented by stations TVBC 26 and TVBC 08, were examined in detail for microbial and biochemical parameters during ABP-04 (March-May, 2005). Station TVBC $26\left(10^{\circ} \mathrm{S}\right.$, $\left.75.5^{\circ} \mathrm{E}\right)$ lies in the siliceous ooze realm of the northern CIB. Station TVBC $08\left(16^{\circ} \mathrm{S}, 75.5^{\circ} \mathrm{E}\right)$ is a seamount flank in the volcanic realm of pelagic red clays in the southern CIB. Both stations are situated below the calcite compensation depth which is approximately $4500 \mathrm{~m}$ below sea surface (Fig. 1A). Porewater chemistry, porosity, lithology and biostratigraphy were also studied for these two cores during ABP-04. Supporting data on radiometric dating was available from the same locations (BC-26 and BC-08) during an earlier cruise AAS-61 (March-April, 2003). Additional porewater data for $\mathrm{O}_{2}, \mathrm{Mn}, \mathrm{Fe}, \mathrm{NH}_{4}{ }^{+}$, and $\mathrm{HS}^{-}$was acquired from core IVBC 20A, adjacent to TVBC 26, during Cruise ABP-38 (September-October, 2009).

The samples were collected with the help of the United States Naval Electronics Laboratory (USNEL) -type box core of dimensions $50 \mathrm{~cm}$ x $50 \mathrm{~cm}$ x $50 \mathrm{~cm}$. Sub-cores were collected using acrylic cores with a $6.3 \mathrm{~cm}$ inner diameter. The sediment cores were sectioned at $2 \mathrm{~cm}$ intervals up to $10 \mathrm{~cm}$ and at $5 \mathrm{~cm}$ interval thereafter unless mentioned otherwise. The sediments were collected in sterile plastic bags for further processing. Both the cores were analyzed up to $25 \mathrm{~cm}$ bsf (below sea floor). Hard bottom sediments hindered obtaining deeper cores at TVBC 08. Microbial samples were processed onboard at $4{ }^{\circ} \mathrm{C}$ and 1 atm pressure immediately after sediment collection.

\section{Lithology, stratigraphy and age}

Rock colour was analyzed on-board in accordance with the Rock color chart of the Geological Society of America, Boulder, Colorado (Courtesy: Cruise report of ABP-04, NIO, Goa, India). The percentage of sand, silt and clay components was determined from desalted samples according to Folk (1968). A litholog was constructed according to Zervas et al. (2009) using SEDLOG version 2.1.4 software program to show sand, silt and clay content. Neogene radiolarian (NR) biostratigraphy was studied according to Gupta (1991a) and Johnson et al. (1989).

Radiometric dating using ${ }^{230} \mathrm{Th}_{\mathrm{exc}}$ was analysed according to Krishnaswami \& Sarin (1976). Details of analysis are presented in Mascarenhas-Pereira et al. (2006) and Nath et al. (2008). 


\section{Porewater geochemistry and geotechnical properties}

Shipboard analysis of modern porewater $\mathrm{pH}, \mathrm{NO}_{2}{ }^{-}, \mathrm{NO}_{3}{ }^{-}, \mathrm{PO}_{4}{ }^{3-}$ and $\mathrm{SiO}_{3}{ }^{2-}$

was performed using the standard methods described in Grasshoff et al. (1983). Porewater $\mathrm{O}_{2}$, $\mathrm{NH}_{4}{ }^{+}$, and $\mathrm{HS}^{-}$were determined according to Pai et al. (1993), Grasshoff et al. (1983) and Pachmayr (1960), respectively. The determination of $\mathrm{Fe}$, and $\mathrm{Mn}^{-}$in porewater was performed by sampled direct current (Aldrich \& van der Berg, 1998) and differential pulse polarographic (Colombini \& Fuocco, 1983) methods using a Metrohm (Switzerland) voltammeter. Porosity, wet bulk density, water content and specific gravity were measured using the standard method described in ASTM (1995).

\section{Total Organic Carbon (TOC) and C/N ratio}

Total carbon and nitrogen were measured using a NCS 2500 Elemental Analyser (Patience et al., 1990) using a L-Cistina (Therma Quest Italia SpA) as standard. Total carbon was counterchecked with a UIC CM 5014 coulometer and found to be similar in range. Total inorganic carbon was analyzed by a UIC CM 5014 coulometer using $\mathrm{CaCO}_{3}$ (Merck, Germany) as standard. The accuracy of measurements was verified by analysis of a standard reference material (USGS-MAG1). The TOC was determined by subtracting total inorganic carbon from total carbon. The $\mathrm{C} / \mathrm{N}$ was calculated as the ratio between TOC and total nitrogen.

\section{Labile organic matter (LOM)}

Total protein concentrations within sediments were estimated by Lowry's Folin Ciocalteu method using bovine serum albumin as standard (Lowry et al., 1951). Total carbohydrate concentrations within sediments were estimated using the phenol-sulphuric acid method of Kochert (1978) with glucose as standard. Total lipids of sediments were estimated using stearic acid as a standard (Bligh \& Dyer, 1959). The sum of total proteins, carbohydrates and lipids was expressed as LOM. The nature and origin of the organic matter was estimated by the protein /carbohydrate ratio (Cauwet, 1978; Fichez, 1991).

\section{Adenosine Triphosphate (ATP)}

ATP was estimated to determine the total biomass of living organisms in deep-sea sediments by luciferin-luciferase reaction (Holm-Hansen \& Booth, 1966), using adenosine triphosphate disodium salt as standard (Sigma Chemicals, USA). Photons produced were counted on a Perkin Elmer, Wallac 1409 DSA, Liquid Scintillation Counter as counts per minute and converted to ATP equivalents (Delistraty \& Hershner, 1983). 


\section{Bacterial counts}

\section{Total counts of bacteria}

Total bacterial cells were counted according to Hobbie et al. (1977). About $1 \mathrm{~g}$ of sediment was diluted with $9 \mathrm{ml}$ of sterile sea water; $3 \mathrm{ml}$ of this slurry was fixed with buffered formalin at an end concentration of $2 \%$ and stored at $4{ }^{\circ} \mathrm{C}$ until analysis. At the on-shore laboratory the aliquot was sonicated at 15 hertz for $15 \mathrm{sec}$. The supernatant $(1 \mathrm{ml})$ was stained with $75 \mu \mathrm{lof} 0.01 \%$ acridine orange ( $3 \mathrm{~min}$, in dark) and filtered onto $0.22 \mu \mathrm{m}$ black polycarbonate filter paper (Millipore, USA). This procedure minimized masking by sedimentary particles. About 10 to 15 microscopic fields were counted to include a total of 300 to 600 cell counts per sample using a Nikon 80i epifluorescence microscope. The counts were normalized per gram of dry sediment.

Frequency of dividing cells (FDC)

The FDC was enumerated among the total counts (Naganuma et al., 1989) and represented as the natural viable population. In the filtered and stained samples of total bacterial counts, dividing bacteria cells were counted as elaborated above. Bacteria showing an invagination, but not a clear intervening zone between cells were considered as one dividing cell (Hagstrom et al., 1979).

\section{Direct Viable Counts (DVC)}

Direct viable cell numbers (DVC) were determined according to Kogure et al. (1984). Aerobic viable cell numbers (DVC-a) and anaerobic viable cell numbers (DVC-an) were enumerated separately. $3 \mathrm{ml}$ of sediment slurry was prepared as above by diluting $1 \mathrm{~g}$ of sediment with $9 \mathrm{ml}$ of sterile sea water into two sets. The first set was amended with $0.001 \%$ final concentration of yeast extract and $0.0016 \%$ final concentration of an antibiotic cocktail solution containing piromedic, pipemedic and nalidixic acid in the ratio 1:1:1 and incubated statically in the dark at $4{ }^{\circ} \mathrm{C}$ for $30 \mathrm{~h}$. In the second set, used to determine viability under anaerobic conditions, in addition to yeast extract and antibiotic cocktail, $12 \mu \mathrm{l}$ of $\mathrm{Na}_{2} \mathrm{~S} 9 \mathrm{H}_{2} \mathrm{O}$ was added as a reductant at a final concentration of 0.125 $\%$ before incubation (Loka Bharathi et al., 1999). At the end of the incubation the aliquots were fixed with $2 \%$ buffered formalin and stored at $4{ }^{\circ} \mathrm{C}$ until analysis.

The cocktail composition was suitably modified from Joux \& Lebaron (1997) by using three out of five antibiotics. Antibiotics were dissolved in $0.05 \mathrm{M} \mathrm{NaOH}$ [nalidixic, piromidic, and pipemidic acids (Sigma)]. All antibiotic solutions were filter sterilized through $0.2 \mathrm{~mm}$ pore-size membrane filters (Millipore, USA) before use. 
The addition of yeast extract in low concentrations permits cell growth and replication of nucleic acid but the antibiotic cocktail prevents cell division for the period of incubation. The elongated and enlarged dividing cells were counted as aerobic viable counts (DVC-a) or anaerobic viable counts (DVC-an) using a similar procedure to that employed for total counts (Kogure et al., 1984).

\section{Heterotrophic counts}

Colony forming units on varying concentrations of ZoBell Marine Agar (ZMA) were assessed using three different concentrations of ZoBell Marine broth 2216 (Himedia, Mumbai, India) in $1.5 \%$ agar (Difco) namely, 100, 50 and 12.5\%. The 100\% concentrated broth was prepared according to manufacturers' instructions, while $50 \%$ and $12.5 \%$ were diluted to half and one-eighth strengths respectively with a final $\mathrm{pH}$ of $7.6 \pm 0.2$ (ZoBell, 1941). The plates were incubated at 2 to $5^{\circ} \mathrm{C}$. Heterotrophic colonies appeared within 4 to 10 days.

\section{Potential autotrophs}

Nitrifying bacteria were enumerated on modified Winogradsky's media for ammonia oxidizers and nitrite oxidizers by substituting the medium with (NH4) ${ }_{2} \mathrm{SO}_{4}$ at $2 \mathrm{mM}$ (final concentration) or $\mathrm{NaNO}_{2}$ at $0.5 \mathrm{mM}$ (final concentration) as an energy source (Ram et al., 2001). The medium for aerobic sulphur oxidizing bacteria was similar to that of denitrifiers as described below except for the addition of $\mathrm{KNO}_{3}$. Inoculation for all oxidizers was done by standard plating techniques.

Nitrate reducers were enumerated on modified Leiske's medium (Loka Bharathi, 1989; Loka Bharathi \& Chandramohan, 1990; Loka Bharathi et al., 2004). The bacteria cultured on this medium reduce nitrate at the expense of thiosulphate. For simplicity this group is identified as denitrifiers in the rest of the manuscript as these are known to be functionally similar to Thiobacillus denitrificans. Medium composition per litre of aged sea water: $\mathrm{Na}_{2} \mathrm{~S}_{2} \mathrm{O}_{3} 5 \mathrm{H}_{2} \mathrm{O}-5 \mathrm{~g}, \mathrm{~K}_{2} \mathrm{HPO}_{4}-0.2$ g, $\mathrm{MgCl}_{2} 6 \mathrm{H}_{2} \mathrm{O}-$ $0.1 \mathrm{~g}, \mathrm{CaCl}_{2} 6 \mathrm{H}_{2} \mathrm{O}-0.01 \mathrm{~g}, \mathrm{FeCl}_{3} 6 \mathrm{H}_{2} \mathrm{O}-0.01 \mathrm{~g}$, phenol red indicator- $0.01 \mathrm{~g}$, pure agar (Difco)- 10 $\mathrm{g}, \mathrm{NaHCO}_{3}-1 \mathrm{~g}, \mathrm{pH} 8$ to 8.3 . $\mathrm{KNO}_{3}$ at $1 \mathrm{~g} \mathrm{l}^{-1}$ was added as a terminal electron acceptor. Sodium bicarbonate solution was filter sterilized and added to the medium just before inoculation. A second group of nitrate reducing bacteria that reduce nitrate at the expense of organic matter were enumerated. For simplicity, this group is identified as nitrate reducing bacteria (NRB). Medium composition per litre of aged sea water: $0.101 \mathrm{~g} \mathrm{KNO}_{3}$ and nutrient agar at a $\mathrm{pH}$ of 7.5 to 8 . The original $14 \mathrm{~g} \mathrm{l}^{-1}$ of nutrient agar was modified to $25 \%$ strength of nutrient broth amended with pure 
agar to give a final agar concentration of $0.8 \%$. Reducers were inoculated in agar-shake tubes as described in Loka Bharathi (1989).

Fe-oxidizers were cultivated on iron oxidizers medium (Himedia, Mumbai, India). Two parts $\mathrm{A}$ and $\mathrm{B}$ of the medium were prepared separately. Part A consisting of $\left(\mathrm{NH}_{4}\right)_{2} \mathrm{SO}_{4}-3.0 \mathrm{~g}, \mathrm{KCl}-0.10$ $\mathrm{g}, \mathrm{K}_{2} \mathrm{HPO}_{4}-0.5 \mathrm{~g}, \mathrm{MgSO}_{4}-0.5 \mathrm{~g}, \mathrm{Ca}\left(\mathrm{NO}_{3}\right)_{2}-0.01 \mathrm{~g}$ was dissolved in $700 \mathrm{ml}$ of sea water containing $1 \mathrm{ml}$ of $10 \mathrm{~N} \mathrm{H}_{2} \mathrm{SO}_{4}$. Part B containing $44.22 \mathrm{~g}$ of $\mathrm{FeSO}_{4}$ was dissolved in $300 \mathrm{ml}$ of distilled water and mixed to Part A. The final salinity was adjusted to $35 \mathrm{ppt}$ and the final $\mathrm{pH}$ was adjusted to $6.8+$ 0.2 in order to maintain a mild acidic to near neutral condition (Rodina, 1972).

Mn-oxidizers were cultivated on modified Beijerinck's medium (Rodina, 1972, Havert, 1992). Two parts $\mathrm{A}$ and $\mathrm{B}$ of the medium were prepared separately. Part A consisting of $\mathrm{NaHCO}_{3}$ $0.1 \mathrm{~g},\left(\mathrm{NH}_{4}\right)_{2} \mathrm{SO}_{4^{-}} 0.1 \mathrm{~g}, \mathrm{~K}_{2} \mathrm{HPO}_{4}-0.5 \mathrm{~g}, \mathrm{MgSO}_{4^{-}} 0.5 \mathrm{~g}$, was dissolved in $900 \mathrm{ml}$ of sea water. Part $\mathrm{B}$ containing $12.5 \mathrm{~g}$ of $\mathrm{MnCl}_{2}$ was dissolved in $100 \mathrm{ml}$ of distilled water and mixed to Part $\mathrm{A}$. The final salinity was adjusted to $35 \mathrm{ppt}$ and the final $\mathrm{pH}$ was adjusted to $7.8 \pm 0.2$ in order to maintain a near neutral condition.

\section{Microbial uptake of carbon in sediments}

Microbial uptake of carbon in sediments was measured using $\mathrm{NaH}^{14} \mathrm{CO}_{3}$ uptake $[5 \mu \mathrm{Ci} / \mathrm{ml}$ activity, Board of Radiation and Isotope Technology (BRIT), Navi Mumbai, India] adopting methods described earlier (Nelson et al., 1989; Tuttle \& Jannasch, 1977). Briefly, about $1 \mathrm{~g}$ of sediment was suspended in $9 \mathrm{ml}$ sterile sea water and this sediment slurry was incubated with $0.08 \mu \mathrm{Ci} \mathrm{ml} \mathrm{m}^{-1}$ final concentration of $\mathrm{NaH}^{14} \mathrm{CO}_{3}$ at $4{ }^{\circ} \mathrm{C}$ with $24 \mathrm{~h}$ incubation in the dark. Unincorporated labelled carbon was carefully washed with sterile sea water. The filtered slurry was acidified to remove unbound ${ }^{14} \mathrm{C}$ and trace inorganic carbon. The filter with the trapped sediment was further dried at $35^{\circ} \mathrm{C}$ and then suspended in a scintillation vial containing cocktail. The sample was counted after 12 to $24 \mathrm{~h}$ in a Liquid Scintillation counter (Model Perkin Elmer, Wallac 1409 DSA). Suitable controls for unlabelled and heat killed sediments, wash water and labelled carbon were included. The incorporation of carbon was read as disintegrations per minute (integrated for 5 min) and was expressed as nmol $\mathrm{C} \mathrm{g}^{-1} \mathrm{day}^{-1}$.

\section{Calculations of organic carbon flux from surface primary productivity}

The organic carbon flux to the sea floor was derived (Schenau et al., 2000) from previously reported productivity values based on values of ${ }^{14} \mathrm{C}$ incorporation by primary productivity (Matondkar et al., 2005). The net primary productivity was derived from the difference between light 
and dark bottle incubations in this study. The calculations below consider only this net primary productivity. Potential carbon flux to the sea floor $\mathrm{J}_{\mathrm{Cx}=0}$ was calculated using the relationship:

$$
J_{C x=0}=2 P P^{0.5} \times(P P / 100) x(1 / z+0.025)
$$

where, $\mathrm{PP}=$ Integrated column productivity rate in $\mathrm{g} \mathrm{C} \mathrm{m}^{-2} \mathrm{yr}^{-1}$,

$\mathrm{z}=$ water depth expressed in 100 s of metres (i.e., $5000 \mathrm{~m}$ depth is expressed as $50 \mathrm{x} 100$, where $\mathrm{z}=50$;

Schenau et al., 2000)

Accumulation rate of sediment at the sea floor was calculated as a product of sedimentation rate and dry bulk density as:

$$
\text { Sediment accumulation rate, } S_{a c c}=S \rho(1-\varphi)
$$

where, $S=$ linear sedimentation rates $\left(0.834\right.$ and $0.041 \mathrm{~cm} \mathrm{kyr}^{-1}$ in TVBC 26 and TVBC 08 respectively), $\rho=$ wet bulk density in $\mathrm{g} \mathrm{cm}^{-3}$ and $\varphi=$ porosity.

Accumulation rate of carbon at the sea floor was calculated as a product of sediment accumulation rate and $\mathrm{C}_{\text {org }}(\%)$ as:

$$
C_{\text {org }} x S_{a c c}
$$

Preservation factor was calculated as the ratio of the rate of carbon accumulation to primary production rate (Wenbo et al., 2008). Palaeoproductivity (PaP) was calculated from TOC:

$$
P a P=5.31[C(\rho-1.026 \varphi / 100)]^{0.71} S^{0.07} Z^{0.45}
$$

$\mathrm{PaP}$ is a function of carbon flux near the sea floor and is related to both productivity and water depth (Stein, 1991) and expressed as $\mathrm{gC} \mathrm{m}^{-2} \mathrm{kyr}^{-1}$. PaP profiles are compared to those of autotrophic microbial carbon fixation profiles to understand time-dependent variations in the extent of chemoautotrophy.

\section{Data analysis and statistical significance}

In the case of epifluorescence counts, 10 to 15 microscopic fields cumulating in not less than 500 cells were considered for deriving standard deviations. Plate counts, $\mathrm{ATP}, \mathrm{NaH}^{14} \mathrm{CO}_{3}$ uptake and LOM were analyzed in triplicate. All parameters were normalized per gram of sediment dry weight unless mentioned otherwise. Parameters were plotted as averaged profiles with error bars representing the range of individual samples. Two-factor analysis of variance (ANOVA) without replication was used for confirming significance in variations. Correlation between the TOC 
contents, microbial, biochemical parameters and porewater data were analyzed for Spearman's Rank correlation using Statistica version 6.

\section{Quantification of the influence of non-steady state diagenetic condition on microbial community by numerical simulation}

A non-steady state diagenetic model was considered to explain the formation of the tan green mottled zone showing chemoautotrophy in core TVBC 26. Transient diffusion model (Meister et al., 2007) including a sink term, was used to simulate $\mathrm{NO}_{3}{ }^{-}$porewater profiles as shown in equation 5:

$$
\partial c / \partial t=\kappa\left(\partial^{2} c / \partial x^{2}\right)+s(x)
$$

where, $\mathrm{c}(\mathrm{x}, \mathrm{t})$ is the concentration of $\mathrm{NO}_{3}{ }^{-}(\mu \mathrm{M}), \mathrm{t}$ is time $(\mathrm{yr})$, and $\mathrm{x}$ is the depth below sea floor $(\mathrm{cm}$ bsf).

$$
\kappa=\varphi \tau^{-2} D_{s} \text { and } \tau^{2}=\varphi F
$$

where, $D_{s}$ is the diffusion coefficient for $\mathrm{NO}_{3}{ }^{-}\left(\mathrm{m}^{2} \mathrm{~s}^{-1}\right), \varphi$ is the porosity (dimensionless) and $\mathrm{F}$ is the formation factor (dimensionless). Nitrite oxidation rate $\mathrm{s}(\mathrm{x})$ and the nitrate reduction rate $\mathrm{s}^{\prime}(\mathrm{x})$ is:

$$
\begin{aligned}
& \mathrm{s}(\mathrm{x})=0 \mu \mathrm{mol} \mathrm{m} \mathrm{yr}^{-1}, \text { if } \mathrm{t}<10,000 \mathrm{yr} \\
& \mathrm{s}(\mathrm{x})=1000 \mu \mathrm{mol} \mathrm{m}^{-3} \mathrm{yr}^{-1}, \text { if } 10,000 \mathrm{yr}<\mathrm{t}<11,200 \mathrm{yr} \text { and } 3<\mathrm{x}<7 \mathrm{~cm} \text { bsf } \\
& \mathrm{s}^{\prime}(\mathrm{x})=-1000 \mu \mathrm{mol} \mathrm{m} \mathrm{yr}^{-1}, \text { if } 10,000 \mathrm{yr}<\mathrm{t}<11,200 \mathrm{yr} \text { and } 5<\mathrm{x}<9 \mathrm{~cm} \text { bsf }
\end{aligned}
$$

Thus, $\mathrm{s}(\mathrm{x})$ represents nitrification and is substituted by $\mathrm{s}^{\prime}(\mathrm{x})$ in case of denitrification.

The following initial conditions and boundary conditions were used:

$$
\begin{array}{ll}
c=26.13 \mu \mathrm{M} & \text { for } \mathrm{x}>0 \\
\mathrm{c}=8.87 \mu \mathrm{M} & \text { for } \mathrm{x}=0 \\
\mathrm{c}(0, \mathrm{t})=8.87 \mu \mathrm{M} & \\
\mathrm{c}(\mathrm{L}, \mathrm{t})=26.13 \mu \mathrm{M} &
\end{array}
$$

where, $\mathrm{L}$ is the length of the model domain.

Explicit finite difference method was used to solve equation 5. A time step of 10 years and a grid size of $1 \mathrm{~cm}$ were chosen. Tortuosity factor was calculated from porosity and formation factor (Schulz \& Zabel, 2000). A diffusion coefficient for $\mathrm{NO}_{3}{ }^{-}$of $9.03 \mathrm{E}-10 \mathrm{~m}^{2} \mathrm{~s}^{-1}$, at $0^{\circ} \mathrm{C}$ was considered (Schulz \& Zabel, 2000). Both s(x) and s'(x) = 0 for the first 10,000 years of the computation, which is the time required for an organic matter pulse to reach the present tan-green mottled zone at 13 to 
$25 \mathrm{~cm}$ bsf without being diagenetically altered. After setting these conditions, nitrite oxidation and nitrate reduction are switched on separately in the depth interval $3<\mathrm{x}<7 \mathrm{~cm}$ bsf and $5<\mathrm{x}<9 \mathrm{~cm}$ bsf respectively to simulate the effect of strong nitrite oxidation followed by nitrate reduction in an organic carbon-rich sediment layer. A nitrite oxidation rate of $1000 \mu \mathrm{M} \mathrm{m}^{-3} \mathrm{yr}^{-1}$ was assumed in a horizon from 3 to $7 \mathrm{~cm}$ bsf (Ward et al., 1989). In the horizon from 5 to $9 \mathrm{~cm}$ bsf a maximum nitrate reduction rate of $-1000 \mu \mathrm{M} \mathrm{m}^{-3} \mathrm{yr}^{-1}$ was assumed.

\section{Quantification of hydrothermal alterations on porewater and microbial community by numerical simulation}

A modified transient diffusion model (Meister et al., 2007) including a source term was considered to explain the influence of hydrothermal activity on the porewater profile. This model in turn was used to explain the enhanced chemoautotrophic microbial activity at the PleistoceneTertiary stratigraphic transition zone of core TVBC 08 . Porewater $\mathrm{NO}_{3}{ }^{-}$profiles were simulated as shown in equation 7 :

$$
\partial c / \partial t=\kappa^{\prime}\left(\partial^{2} c / \partial x^{2}\right)+s r(x)
$$

where, $\mathrm{c}(\mathrm{x}, \mathrm{t})$ is the concentration of $\mathrm{NO}_{3}{ }^{-}(\mu \mathrm{M}), \mathrm{t}$ is time $(\mathrm{yr})$, and $\mathrm{x}$ is the depth below sea floor $(\mathrm{cm}$ bsf).

$$
\kappa^{\prime}=\varphi \tau^{-2} D_{s} \text { and } \tau^{2}=\varphi F^{\prime}
$$

where, $D_{s}$ is the diffusion coefficient for $\mathrm{NO}_{3}{ }^{-}\left(\mathrm{m}^{2} \mathrm{~s}^{-1}\right), \varphi$ is the porosity (dimensionless) and $\mathrm{F}$ is the formation factor (dimensionless). Nitrite oxidation rate $\operatorname{sr}(\mathrm{x})$ and the nitrate reduction rate $\operatorname{sr}^{\prime}(\mathrm{x})$ is:

$$
\begin{aligned}
& \operatorname{sr}(\mathrm{x})=0 \mu \mathrm{mol} \mathrm{m} \mathrm{yr}^{-1}, \text { if } \mathrm{t}<1000 \mathrm{yr} ; \\
& \operatorname{sr}(\mathrm{x})=1000 \mu \mathrm{mol} \mathrm{m} \mathrm{yr}^{-1}, \text { if } 1000 \mathrm{yr}<\mathrm{t}<1170 \mathrm{yr} \text { and } 3<\mathrm{x}<7 \mathrm{~cm} \mathrm{bsf} \\
& \operatorname{sr}^{\prime}(\mathrm{x})=-1000 \mu \mathrm{mol} \mathrm{m} \mathrm{yr}^{-1}, \text { if } 1000 \mathrm{yr}<\mathrm{t}<1170 \mathrm{yr} \text { and } 5<\mathrm{x}<9 \mathrm{~cm} \text { bsf }
\end{aligned}
$$

Thus, $\operatorname{sr}(\mathrm{x})$ represents nitrification and is substituted by $\mathrm{sr}^{\prime}(\mathrm{x})$ in the case of denitrification.

The following initial conditions and boundary conditions were used:

$$
\begin{array}{ll}
c=9.71 \mu \mathrm{M} & \text { for } \mathrm{x}>0 \\
\mathrm{c}=4.85 \mu \mathrm{M} & \text { for } \mathrm{x}=0 \\
\mathrm{c}(0, \mathrm{t})=4.85 \mu \mathrm{M} & \\
c(L, t)=9.71 \mu \mathrm{M} &
\end{array}
$$

where, $\mathrm{L}$ is the length of the model domain. 
Explicit finite difference method was used to solve equation 7. A time step of 1 year and a grid size of $1 \mathrm{~cm}$ were chosen. Tortuosity factor was calculated from porosity and formation factor (Schulz \& Zabel, 2000). A diffusion coefficient for $\mathrm{NO}_{3}{ }^{-}$of $9.03 \mathrm{E}-10 \mathrm{~m}^{2} \mathrm{~s}^{-1}$, at $0^{\circ} \mathrm{C}$ was considered (Schulz \& Zabel, 2000). Both $\operatorname{sr}(\mathrm{x})$ and $\operatorname{sr}^{\prime}(\mathrm{x})=0$ for the first 1000 years of the computation, when up-welling of hydrothermally derived $\mathrm{NO}_{3}{ }^{-}$occurs as a focused jet to the present Pleistocene-Tertiary stratigraphic transition zone at 3 to $12 \mathrm{~cm}$ bsf without being dispersed laterally. After setting these conditions, nitrite oxidation and nitrate reduction are switched on separately in the depth interval $3<$ $\mathrm{x}<7 \mathrm{~cm}$ and $5<\mathrm{x}<9 \mathrm{~cm}$ bsf respectively. The effect of strong nitrite oxidation followed by nitrate reduction in the stratigraphic transition zone is simulated due to lateral dispersion and phase separation of solutes carried upward by the hydrothermal fluid and resultant microbial activity. A nitrite oxidation rate of $1000 \mu \mathrm{M} \mathrm{m}^{-3} \mathrm{yr}^{-1}$ was assumed in a horizon from 3 to $7 \mathrm{~cm}$ bsf (Ward et al., 1989). In the horizon from 5 to $9 \mathrm{~cm}$ bsf a maximum nitrate reduction rate of $-1000 \mu \mathrm{M} \mathrm{m}^{-3} \mathrm{yr}^{-1}$ was assumed. The model source code in MATLAB 7.0.4 used for this work is available as a doc-file and provided as an electronic supplement to this paper.

\section{RESULTS}

\section{NORTHERN CORE TVBC 26}

\section{Lithology, stratigraphy and age}

The siliceous core TVBC 26 shows tan-green mottled transitions, a distinct feature in northern CIB sediments. Here the moderate yellowish brown (10YR 4/2) sediments from 13 to 25 $\mathrm{cm}$ bsf showed intense mottling with light olive grey (5Y 5/2) and dark yellowish brown (10YR 4/2) continuous intercalations. The surface of both cores BC 26 and reoccupied station TVBC 26 were covered with Mn nodules (Cruise Reports of AAS-61 and ABP-04, unpublished), indicating that the surface was preserved during sample retrieval (Borole, 1993). The sediment of core TVBC 26 is composed of 0.37 to $4.17 \%$ sand, 25.37 to $49.45 \%$ silt and 49.2 to $74.10 \%$ clay. Sand content $\leq 4 \%$ and is not resolvable in the litholog (Fig. 2).

Neogene radiolarian (NR) biostratigraphy of the core TVBC 26 suggested that the first appearance of index species Collospheara invaginata is $24 \mathrm{~cm}$ bsf, representing an approximate date of ca 180ka (Johnson et al., 1989). C. tuberosa and C. orthoconus are present from 16 to $3 \mathrm{~cm}$ core depth. Most importantly, Stylatractus universus is conspicuously absent suggesting that the base of

the core was younger than ca 300ka (Fig. 2). Biostratigraphic sedimentation rate of $c a 1.1 \mathrm{~mm} \mathrm{kyr}^{-1}$ was consistent with previous findings (Banakar et al., 1991 and Borole, 1993). However, 
radiometric dating from the same location (BC 26, AAS-61) using ${ }^{230} \mathrm{Th}_{\mathrm{exc}}$ showed a much higher sedimentation rate of $8.34 \mathrm{~mm} \mathrm{kyr}^{-1}$ (Fig. 2).

\section{Porewater geochemistry and geotechnical properties}

The porewater of TVBC 26 was nearly neutral, with $\mathrm{pH}$ averaging $7.30 \pm 0.07$ (Fig. 3A). $\mathrm{NO}_{2}{ }^{-}$concentrations up to $0.14 \mu \mathrm{M}$ were detected only in the top 0 to $2 \mathrm{~cm}$. The $\mathrm{NO}_{3}{ }^{-}$concentration averaged at $21.83 \pm 5.97 \mu \mathrm{M}, \mathrm{PO}_{4}{ }^{3-}$ at $1.79 \pm 0.20 \mu \mathrm{M}$ and $\mathrm{SiO}_{3}{ }^{2-}$ at $478 \pm 74 \mu \mathrm{M}$ (Fig. 3A). Porosity at the tan-green mottled zone shows a decrease indicating relative compaction. Porewater $\mathrm{O}_{2}, \mathrm{Mn}$, $\mathrm{Fe}, \mathrm{NH}_{4}{ }^{+}$and $\mathrm{HS}^{-}$concentrations were obtained from a neighbouring siliceous core IVBC 20A (Fig. 3B). Like TVBC 26, this core also showed mottled structures at 12 to $19 \mathrm{~cm}$ bsf. The oxygen concentrations varied from 180 to $370 \mu \mathrm{M} \mathrm{l}^{-1}$ with peaks at 10 and $20 \mathrm{~cm}$ bsf indicating consumption of oxygen at the reactive layers above $10 \mathrm{~cm}$ and mottles above $20 \mathrm{~cm}$. Ammonium concentrations varied from non detectable to $0.14 \mu \mathrm{M}^{-1}$ of porewater with peaks generally corresponding to oxygen depletion. Sulphide concentrations varied from 0.03 to $0.18 \mu \mathrm{M}^{-1}$ with peak concentration at $7 \mathrm{~cm}$ bsf. Mn concentrations varied from 0.14 to $9.95 \mathrm{mg}^{-1}$ with peaks above 7 and $19 \mathrm{~cm} \mathrm{bsf.} \mathrm{Fe}$ concentrations varied from 0.39 to $9.94 \mathrm{mg} \mathrm{l}^{-1}$ with highest peak at $17 \mathrm{~cm}$ bsf (Fig. 3B)

\section{TOC, TIC and C/N-ratio}

The northern siliceous sediment TVBC 26 was twice as rich in TOC when compared to the pelagic red clays from the southern TVBC 08 (Fig. 2). The averaged down-core TOC profile of siliceous TVBC 26 was 0.15 to $0.45 \%$. The TIC varied from non detectable to $<0.1 \mathrm{ppm}$. TIC was detected only at 2 to 4 and 20 to $25 \mathrm{~cm}$ bsf. A TOC peak at 2 to $4 \mathrm{~cm}$ bsf was followed by a TIC peak at 4 to $6 \mathrm{~cm}$ bsf in the reactive layer 1 . TIC showed a tendency to increase at the sub-oxic mottledzone. TVBC 26 showed a $\mathrm{C} / \mathrm{N}$-ratio ranging from 4 to 8.3 . At the sub-oxic mottle (15 to $25 \mathrm{~cm}$ bsf) ratio was 28.6 (Fig. 2).

\section{Labile Organic Matter (LOM)}

Though carbohydrates and lipids were almost similar, proteins were four times higher in TVBC 26 than its southern counterpart. Protein/carbohydrate ratios were $>1$ at TVBC 26 indicating fresher LOM contents. Significant variations in down-core profiles of all parameters were noted at the reactive layer of TVBC 26 (Fig. 4). In the tan-green mottled zone of TVBC 26 the carbohydrates show relatively better preservation and coincided with a higher $\mathrm{C} / \mathrm{N}$ ratio (Fig. 2), increasing ATP (Fig. 5) higher aerobic sulphur oxidizers (Fig. 6A) and higher carbon uptake (Fig. 7) indicating a chemo-autotrophic pocket in a predominantly heterotrophic setting. 


\section{Adenosine triphosphate (ATP)}

In TVBC 26 the values ranged from 50 to $105 \mathrm{ng} \mathrm{g}^{-1}$ dry wt with the highest value at 20 to $25 \mathrm{~cm}$ bsf (Fig. 5).

\section{Bacterial counts}

Total bacterial counts and Frequency of dividing cells (FDC)

The total bacterial counts in core TVBC 26 varied from $3.6 \mathrm{E}+08$ to $7.2 \mathrm{E}+08$ cells $\mathrm{g}^{-1}$. Downcore profile was almost homogenous. In core TVBC $26,14 \%$ of the total bacteria were naturally viable. The FDC was two and a half times higher in the surface layer of 0 to $10 \mathrm{~cm}$ at TVBC 26 than in the subsequent sub-surface layer (Fig. 5).

Direct viable counts (DVC-a and DVC-an)

DVC-an was three times higher at the TOC-rich TVBC 26 than at TVBC 08 (p>0.05) (Fig. 5). Prominent variations in TC, FDC, DVC-a and DVC-an are seen at or near the reactive layer 1. DVC-an shows an increase in the sub-oxic mottled zone of TVBC 26.

\section{Heterotrophic counts}

Triplicate plate counts on ZMA showed that the retrievability from organic-rich TVBC 26 was strangely lower than TVBC 08 with a few exceptions. A conspicuous depletion of heterotrophs on $12.5 \%$ ZMA was noted at the tan green mottled colour transition zone (Fig. 6A).

\section{Potential autotrophs}

The ammonium and nitrite oxidizer population was generally lower in TVBC 26 than the southern counterpart. The aerobic sulphur oxidizers, however, followed a different pattern with the average values at TVBC 26 being nearly four times the value in TVBC 08 (Fig. 6A and B). The deep sea bacterial isolates from the CIB were able to grow almost equally well at 28 and $5^{\circ} \mathrm{C}$. Nitrifiers and aerobic sulphur oxidizers appeared within 10 to 35 days. Culturable denitrifiers and nitrate reducers generally took longer to grow than aerobe. The incubation period was often as long as 3 to 12 months, or more, at $5^{\circ} \pm 2^{\circ} \mathrm{C}$.

Denitrifiers showed peak culturablity at 4 to $6 \mathrm{~cm}$ bsf (in between reactive layers 1 and 2) with $10^{3} \mathrm{cfu} \mathrm{g}^{-1}$ dry sediment in the northern TOC-rich core. A second peak with $10 \mathrm{cfu}^{-1}$ dry sediment was seen at the commencement of the mottled zone. The NRB that are dependent on organic matter showed two peaks at 2 to 4 and 6 to $8 \mathrm{~cm}$ bsf with 670 and $20 \mathrm{cfu} \mathrm{g}^{-1}$, respectively. An 
increase in NRB counts was noted at the tan-green mottled zone perhaps representing the remnant of an older reaction front (Fig. 6A).

Fe-oxidizers varied from $1.11 \mathrm{E}+02$ to $1.12 \mathrm{E}+03 \mathrm{cfu} \mathrm{g}^{-1}$ in the northern core TVBC 26 . Mnoxidizers varied from $2.22 \mathrm{E}+02$ to $1.06 \mathrm{E}+03 \mathrm{cfu} \mathrm{g}^{-1}$ in core TVBC 26 . The peaks of Mn- oxidizers lie in the reactive layers and tan-green mottled zone (Fig. 6A). The porewater Mn profile of a similar neighbouring core, IVBC 20A (Fig. 3B), corroborates with that of Mn-oxidizers of core TVBC 26.

\section{Microbial uptake of carbon in sediments}

Measurement of autotrophic microbial carbon fixation by whole sediment slurries showed maximum uptake at 4 to $6 \mathrm{~cm}$ bsf and 20 to $25 \mathrm{cmbsf}$ in core TVBC 26 . The heat killed controls showed markedly lower values than the actual experimental uptake (Fig. 7).

\section{Organic carbon flux, palaeoproductivity and modern microbial autotrophic uptake}

The rate of column productivity recorded over the siliceous oozes was $103 \mathrm{mg} \mathrm{C} \mathrm{m}^{-2} \mathrm{day}^{-1}$ corresponding to 18.91 to $37.74 \mathrm{~g} \mathrm{C} \mathrm{m}^{-2} \mathrm{yr}^{-1}$ (Matondkar et al., 2005). About 0.4 to $0.6 \%$ of carbon from surface production reaches the sea floor as organic carbon flux over the northern siliceous ooze of TVBC 26. The organic C-flux was between 0.07 to $0.205 \mathrm{~g} \mathrm{C} \mathrm{m}^{-2} \mathrm{yr}^{-1}$. The corresponding carbon accumulation rates were $0.028 \mathrm{~g} \mathrm{C} \mathrm{m}^{-2} \mathrm{yr}^{-1}$. Preservation factors for these sediments were extremely low with $1.04 \times 10^{-6}$ for siliceous TVBC 26. Palaeoproductivity calculated from organic carbon content in the sediment cores ranged from 0.097 to $0.157 \mathrm{~g} \mathrm{C} \mathrm{m}^{-2} \mathrm{kyr}^{-1}$ in the siliceous oozes. This palaeoproductivity profile was compared to autotrophic carbon uptake in the present Quaternary times. The modern microbial autotrophic uptake profile showed a similar trend to the palaeoproductivity profile except at 3 to 5 and 20 to $25 \mathrm{~cm}$ bsf where the trend was opposite. This trend was observed at the reactive layer (age 6kyr) and the tan-green mottled transition (age 24kyr) (Fig. 8). Here, the low surface productivity layer was superimposed on a layer with high chemosynthetic activity.

\section{Inter-relationship between bacterial and geochemical parameters in Northern core TVBC 26}

The TOC and LOM significantly correlated to each other $(\mathrm{p}>0.05)$ highlighting the interdependence of organic flux to sea floor and lability of organic matter enhanced by bacteria. TOC related to porewater $\mathrm{pH}$, nitrite oxidizers, carbon uptake rates $(\mathrm{p}>0.01)$ and to ammonium oxidizers $(\mathrm{p}>0.05)$ signifying its stimulatory role on the microbial population while promoting diagenetic reactions. LOM determined total bacterial counts, FDC, DVC-a and heterotrophs recoverable on 50\% ZMA $(\mathrm{p}>0.05)$. These relations are suggestive of aerobic heterotrophic degradation of organic matter. Porewater $\mathrm{NO}_{2}^{-}$showed a negative relationship with $\mathrm{NO}_{3}{ }^{-}(\mathrm{p}>0.01)$, 
$\mathrm{SiO}_{3}{ }^{2-}(\mathrm{p}>0.001)$, TOC $(\mathrm{p}>0.05)$ and ammonium oxidizers $(\mathrm{p}>0.001)$ indicating coupling of heterotrophic degradative process with nitrification during early diagenetic reactions. The ${ }^{14} \mathrm{C}$ uptake $(\mathrm{p}>0.05)$ is positively correlated with nitrite oxidizers. The strong correlation at $\mathrm{p}>0.001$ existed between aerobic sulphur oxidizers and DVC-an suggesting their affinity with facultative anaerobic heterotrophy.

\section{Quantification of the influence of non-steady state diagenetic condition on microbial community by numerical simulation}

The $\mathrm{NO}_{3}^{-}$concentration profile measured by shipboard analysis was simulated using a transient diffusion numeric model (Fig. 9A). At the sea floor interface, the observed $\mathrm{NO}_{3}{ }^{-}$ concentration of $8.87 \mu \mathrm{M}$ was used as a starting condition. It is also assumed that $\mathrm{NO}_{3}{ }^{-}$in sediment porewater is 0 . The model calculated the concentration as a function of time and depth. Considering the residence time of $\mathrm{NO}_{3}{ }^{-}$and the sedimentation rate of an organic matter pulse, a 10,000 years time scale is required for $\mathrm{NO}_{3}{ }^{-}$to reach $17.5 \mathrm{~cm}$ bsf. Assuming a surface layer with a nitrite oxidation rate of $1000 \mu \mathrm{M} \mathrm{m}^{-3} \mathrm{yr}^{-1}$ in the section 3 to $7 \mathrm{~cm}$ bsf, the model also shows that the reactant, $\mathrm{NO}_{2}^{-}$, will be consumed within a time period of 1000 years in this zone. Conversely, at 5 to $9 \mathrm{~cm}$ bsf the reactant $\mathrm{NO}_{3}{ }^{-}$would be reduced at a reduction rate of $-1000 \mu \mathrm{M} \mathrm{m}^{-3} \mathrm{yr}^{-1}$. The reactant $\mathrm{NO}_{3}{ }^{-}$will be consumed within 1000 years. The profile returns to its original shape within another 1000 years soon after the consumption of $\mathrm{NO}_{2}{ }^{-}$in the upper 3 to $7 \mathrm{~cm}$ layer and the simultaneous reduction of $\mathrm{NO}_{3}{ }^{-}$in the lower 5 to $9 \mathrm{~cm}$ ceases. In both halves of the reaction couple a steady nitrification profile is finally achieved and they reproduce the porewater $\mathrm{NO}_{3}{ }^{-}$profile measured in the core TVBC 26 (Fig. 9A), showing net nitrification. The effect of advection in this single core system is neglected. This is because the variations in TOC (Fig. 2) are more important than the variation in porosity (Fig. 3).

\section{SOUTHERN CORE TVBC 26}

\section{Lithology, stratigraphy and age}

The recently reoccupied location TVBC 08 was a different colour than the earlier occupied station BC 08 . The sediment of core TVBC 08 was composed of 0.19 to $0.56 \%$ sand, 16.85 to $26.92 \%$ silt and 72.18 to $82.84 \%$ clay (Figs 1 and 2 ).

In core TVBC $08, C$. invaginata and C. tuberosa are found only in the 0 to $2 \mathrm{~cm}$ section, representing an approximate date of $c a 180 \mathrm{ka}$, while $S$. universus and older index fossils are not found in the core suggesting that the top 0 to $2 \mathrm{~cm}$ indicating an approximate age of $\mathrm{ca} 180 \mathrm{ka}$. This young layer overlies a very old (pre Quaternary to late Neogene) pelagic clay represented by mineral grains, glass shards, and occasional radiolarian and ichthyoliths at 4 to $18 \mathrm{~cm}$, with little 
biostratigraphic value (Gupta, 1991b). Based on these observations no geological age can be inferred for the older substratum. The biostratigraphic record of TVBC 08 (Cruise ABP 04) is consistent with the published results from station BC 08 (Cruise AAS-61) albeit the precise depth of disappearance of above NR index species (Fig. 2).

\section{Porewater geochemistry and geotechnical properties}

The porewater of core TVBC 08 was marginally more alkaline than the northern core TVBC 26, with the $\mathrm{pH}$ averaging $7.41 \pm 0.07$ (Fig. 3A). $\mathrm{NO}_{2}{ }^{-}$averaged $0.07 \pm 0.05 \mu \mathrm{M}$ and $\mathrm{NO}_{3}{ }^{-} 8.32 \pm$ $6.08 \mu \mathrm{M}$. The $\mathrm{NO}_{2}{ }^{-}$and $\mathrm{NO}_{3}{ }^{-}$concentrations show similar trends and are undetectable at 6 to $8 \mathrm{~cm}$ bsf. Sharp variations in $\mathrm{NO}_{2}^{-}, \mathrm{NO}_{3}^{-}, \mathrm{pH}$ and porosity are seen at the Tertiary-Pleistocene stratigraphic transition at TVBC 08. The $\mathrm{PO}_{4}{ }^{3-}$ concentration averaged $1.39 \pm 0.08 \mu \mathrm{M}$ while silica at $324 \pm 11 \mu \mathrm{M}$ showed a steady profile (Fig. 3A).

\section{TOC, TIC and C/N-ratio}

The TOC content of the southern pelagic red clays TVBC 08 was highly depleted with average down-core TOC profile varying between 0 to $0.24 \%$. TOC depletion was maximum both in the upper stratigraphic transition and in the deeper 15 to $20 \mathrm{~cm}$ bsf layer (Fig. 2). C/N-ratio averages around 5 except for a high peak of 14 at the upper limit of the stratigraphic transition zone ( 2 to $4 \mathrm{~cm}$ bsf) indicating preferential nitrogen loss. At greater depths (15 to $25 \mathrm{~cm} \mathrm{bsf}) \mathrm{C} / \mathrm{N}$-ratios $<1$ were observed indicating relative nitrogen enrichment (Fig. 2). The Tertiary-Pleistocene stratigraphic transition in TVBC 08 coincided with that of geochemical and geotechnical boundaries at 2 to $8 \mathrm{~cm}$ bsf with abrupt changes in the $\mathrm{C} / \mathrm{N}$ ratio, porewater $\mathrm{NO}_{2}^{-}$and $\mathrm{NO}_{3}^{-}$(Fig. 3A).

\section{Labile Organic Matter (LOM)}

LOM values at TVBC 08 were only about $50 \%$ of TVBC 26. Protein/carbohydrate ratios were $<1$ at TVBC 08 , except at 0 to 2 and 6 to $8 \mathrm{cmbsf}$ indicating greater recalcitrance (Cauwet, 1978). Significant variations in down-core profiles of all parameters were noted at the stratigraphic transitions of TVBC 08 (Fig. 4). At the deeper layer at 15 to $20 \mathrm{cmbsf}$, the carbohydrate oxidation coincided with a lower ATP (Fig. 5), higher heterotrophic counts (Fig. 6B) and carbon uptake (Fig. 7) indicating chemo-heterotrophic sections in a predominantly autotrophic core.

\section{Adenosine triphosphate (ATP)}

ATP values were an order higher in TVBC 08 than in northern TVBC 26 with values ranged from 232 to $1069 \mathrm{ng} \mathrm{g}^{-1}$ (Fig. 5). 


\section{Bacterial counts}

Total bacterial counts and frequency of dividing cells (FDC)

The total bacterial counts in core TVBC 08 ranged from $8.9 \mathrm{E}+08$ to $2.0 \mathrm{E}+09 \mathrm{cells} \mathrm{g}^{-1}$. Downcore profiles were almost homogenous (Fig. 5). In core TVBC $08,5 \%$ of the total bacteria were naturally viable. FDC at station TVBC 08 was two times higher in sub-surface depths of 10 to $25 \mathrm{~cm}$ than at the surface (Fig. 5).

Direct viable counts (DVC- $a$ and DVC-an)

DVC-a were nearly two times higher at the southern TVBC 08 than at TVBC 26 but the difference was not statistically significant. Prominent variations in TC, FDC, DVC-a and DVC-an were noted at the upper stratigraphic transition and at the deeper 15 to $20 \mathrm{~cm}$ bsf layer of TVBC 08 (Fig. 5).

\section{Heterotrophic counts}

Triplicate plate counts on ZMA showed that the retrievability from TVBC 08 was generally higher than that from TVBC 26 with a few exceptions. It was more than 15 times higher than TVBC 26 at $100 \%$ ZMA, seven times higher at 50\% ZMA and almost 1.2 times higher at $12.5 \% \mathrm{ZMA}$. A conspicuous peak of $>10^{4}$ cells $\mathrm{g}^{-1}$ of heterotrophs on $50 \%$ ZMA was observed at the stratigraphic transition within the Tertiary sediments (Fig. 6A and B).

Potential autotrophs

Total nitrifiers estimated on mineral agar amended with ammonium salt were 250 times more in TVBC 08. The difference was less in nitrite-amended medium. The retrievability of nitrite oxidizers in TVBC 08 was twice that of TVBC 26 (Fig. 6A and B). Denitrifiers were present uniformly in the southern core TVBC 08 ranging from 250 to $750 \mathrm{cfu}^{-1}$, with an order of magnitude less at 8 to $10 \mathrm{~cm}$ bsf. The NRB were notably absent in the TOC-poor south in contrast to the northern core (Fig. 6A and B).

In core, TVBC 08, both the Fe-oxidizers and Mn-oxidizers were one order higher than in core TVBC 26. Here, Fe-oxidizers varied from 5.33E+03 to $1.39 \mathrm{E}+04 \mathrm{cfu} \mathrm{g}^{-1}$. Mn-oxidizers varied from $3.72 \mathrm{E}+03$ to $1.05 \mathrm{E}+04 \mathrm{cfu} \mathrm{g}^{-1}$ dry sediment. A distinct increase in the abundance of these groups is noted at the stratigraphic transition zones (Fig. 6B). 


\section{Microbial uptake of carbon in sediments}

Measurement of autotrophic microbial carbon fixation by whole sediment slurries showed marked differences, with nearly 30 times more uptake at TVBC 08 than at TVBC 26. Occasionally, at certain depths of TVBC 08 , the carbon uptake was 300 times or more than that of TVBC 26. Core TVBC 08 showed two mid-depth maxima at 6 to $8 \mathrm{~cm}$ and 10 to $15 \mathrm{~cm}$ respectively (Fig. 7).

\section{Organic carbon flux, palaeoproductivity and modern microbial autotrophic uptake}

Pelagic red clays showed a lower productivity of 30 to $50 \mathrm{mg} \mathrm{C} \mathrm{m}^{-2}$ day $^{-1}$ corresponding to 10.95 to $18 \mathrm{~g} \mathrm{C} \mathrm{m}^{-2} \mathrm{yr}^{-1}$ (Matondkar et al., 2005). Less than $0.3 \%$ of carbon produced from surface production rains over reaches the red clays. Organic C-flux was $0.03 \mathrm{~g} \mathrm{C} \mathrm{m}^{-2} \mathrm{yr}^{-1}$ and carbon

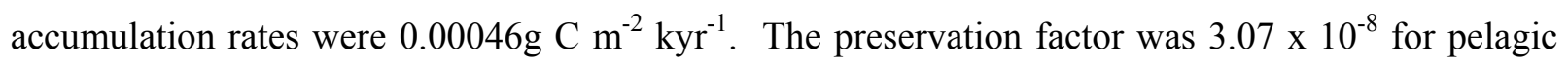
red clay at TVBC 08. Palaeoproductivity ranged from 0.0016 to $0.0097 \mathrm{~g} \mathrm{C} \mathrm{m}^{-2} \mathrm{yr}^{-1}$ in the pelagic red clays (Fig. 8). Palaeoproductivity and modern microbial autotrophic uptake were independent of each other.

\section{Inter-relationship between bacterial and geochemical parameters}

Lower surface productivity (Matondkar et al., 2005), lower sedimentation rates and negligible continental influx are attributed to the low TOC, recalcitrant LOM and the lack of a relationship between the two parameters in the southern TVBC 08 (Figs 2 and 4). The total bacterial counts are dominated by a viable anaerobic population $(\mathrm{p}>0.01)$ that is negatively correlated with TOC, LOM and $\mathrm{C} / \mathrm{N}$ ratio. The ${ }^{14} \mathrm{C}$ uptake correlated positively with total bacterial counts and $(\mathrm{p}>$ $0.05)$.

The ${ }^{14} \mathrm{C}$ uptake related positively only to nitrite oxidizers $(\mathrm{p}>0.05)$ in the north suggesting that chemosynthesis is highly dependent on the reducing agents that are limited in availability. On the contrary, in the southern core the absence of such a relationship suggests that the chemosynthetic activity is not limited either by availability of reduced substrates. Further, this relationship is not restricted to any specific group.

\section{Quantification of hydrothermal alterations on porewater and microbial community by numerical simulation}

The $\mathrm{NO}_{3}^{-}$concentration profile measured by shipboard analysis was simulated using a transient diffusion numeric model (Fig. 9B). At $12.5 \mathrm{cmbsf}$ i.e., below the stratigraphic transition, the observed $\mathrm{NO}_{3}{ }^{-}$concentration of $4.85 \mu \mathrm{M}$ was used as a starting condition. It was also assumed that $\mathrm{NO}_{3}{ }^{-}$in sediment porewater is 0 . The model calculated the concentration as a function of time and 
height of core using the core bottom as height zero. The precise time and duration of the explosion is unknown. However, the alteration features indicate a 200 year time span between the explosion and the present time (Nath et al., 2008). Thus an assumption of a 1000 year focused jet-flow was made to simulate the model. For the first 1000 years of explosive volcanism, $\mathrm{NO}_{3}{ }^{-}$had diffused upwards as a focused jet after which it started dispersing laterally. Assuming a surface layer with a nitrite oxidation rate of $1000 \mu \mathrm{M} \mathrm{m}^{-3} \mathrm{yr}^{-1}$ at 9 to $5 \mathrm{cmbsf}$, the model also shows that the reactant, $\mathrm{NO}_{2}^{-}$, will be dispersed and consumed by microbes within a time period of 100 to 200 years in this zone. Conversely, at 7 to $3 \mathrm{cmbsf}$, the reactant, $\mathrm{NO}_{3}{ }^{-}$will be dispersed and consumed within 100 to 200

years with a nitrate reduction rate of $-1000 \mu \mathrm{M} \mathrm{m}^{-3} \mathrm{yr}^{-1}$. The profile returns to its original shape within another 100 to 200 years soon after the utilization of $\mathrm{NO}_{2}{ }^{-}$in the lower 9 to $5 \mathrm{~cm}$ layer and the simultaneous reduction of $\mathrm{NO}_{3}{ }^{-}$in the upper 7 to $3 \mathrm{~cm}$ ceases. Due to the continuous abiotic supply of $\mathrm{NO}_{2}{ }^{-}$and $\mathrm{NO}_{3}{ }^{-}$, in both halves of the reaction a non-steady nitrification-denitrification coupled profile is sustained and they reproduce the porewater $\mathrm{NO}_{3}{ }^{-}$profile measured in the core TVBC 08 (Fig. 9B).

\section{DISCUSSION}

Although, it was argued that the culturable fraction could wield greater influence on the environment, such inferences remained controversial for two decades, as only 0.001 to $0.01 \%$ of the total bacterial count is amenable to cultivation techniques (Van Es \& Meyer Reil, 1982). Prokaryotic processes are now known to be operating on geological timescales and culturable prokaryotes are reported to be stimulated at interfaces (Parkes et al., 2005). This work reiterates the prevalence of such enhanced bacterial culturability in the CIB that was earlier shown in the Eastern Equatorial Pacific (Parkes et al., 2005; Meister et al., 2007; Wang et al., 2008). This study also demonstrates the occurrence of chemoautotrophic activity coinciding with geochemical and stratigraphic transition zones in both diagenetic and hydrothermally altered sedimentary settings.

\section{NORTHERN CORE TVBC 26}

\section{Influence of organic carbon on microbial carbon uptake}

The comparison of a modern microbial autotrophic uptake profile with the palaeoproductivity profile shows a similar trend suggesting heterotrophy dependent on surface-based production. The microbial degradation and recycling of organic matter is evident in reactive layers 1 and 2 representing two halves of any redox cycle in metabolic zones (Fig. 2; see Schultz, 2000 for detailed definitions). Interestingly, the occurrence of this processes is evident at the tan green colour transition zone (Konig et al., 1997) and appears to have operated at a ca 10,000 years time span on 
the Late Pleistocene-Holocene scale (age derived from ${ }^{230} \mathrm{Th}$ decay). Surprisingly, the biostratigraphic change at $180 \mathrm{ka} \mathrm{BP}$ also coincides with the tan-green mottled zone; however, its relationship with elemental carbon and nitrogen, if any, is not clear (Fig. 2). Although, a clear dependence on surface derived organic matter is shown by the heterotrophic microbes of TVBC 26 , the enhanced chemoautotrophic features at the reactive layers and tan-green transition show that this process is also operational.

\section{Bacteria response to porewater geochemistry in tan green-mottled zone}

The tan-green mottled zones are colour transitions associated with the iron redox boundary. These layers, often referred to as 'sub-oxic' mottles, had been correlated with dissolved $\mathrm{NO}_{3}{ }^{-}, \mathrm{Mn}$ and Fe (Lyle, 1983; Konig et al., 1997). The tan-green mottled zones are found generally below reactive layers 1 and 2 which in turn are prominent below the sediment-water interface (Fig. 2). Formations of these mottles in the Pacific Ocean sediments were attributed to high palaeoproductivity, differential sedimentation rates and fluctuations in oceanic redox conditions caused by changes in bottom water oxygen content (Lyle, 1983). Formation of metal enrichment zones in the upper part of the deep-sea sediment column (Colley et al., 1984; Colley \& Thomas, 1985 ) with the active involvement of microbes (Froelich et al., 1979) are also believed to be the cause of these formations.

Non-steady state diagenetic processes due to downward diffusing oxidants, such as $\mathrm{O}_{2}$ and $\mathrm{NO}_{3}{ }^{-}$, result in the depletion of initially deposited organic carbon. Both oxidized and reduced forms of nitrogen are produced in the active oxidation zones (Buckley \& Cranston, 1988). More recently, the temporal shift of geochemical interfaces from shallower temporary reactive to deeper layers result in mottle formation in predominantly detrital settings (Meister et al., 2007, 2009).

Tan-green transitions in the sediment columns from the northern CIB were reported to influence porewater and sedimentary organic carbon profiles. Extensive nitrification coupled with oxic respiration and the possible involvement of bacteria was previously suggested (Nath \& Mudholkar, 1989). However, the relevant direct microbial evidence is now presented in this study. Microbiologically, the zone is characterized by an increasing trend of ${ }^{14} \mathrm{C}$ uptake and higher values for the C/N-ratio, ATP, DVC-an and denitrifiers (Figs 2, 5, 6 and 7A). Higher C/N ratios in sub-oxic depths of sediments with TOC $<1 \%$ has been associated with bacterial oxidation of metals (Farrimond et al., 1989) and reworking of residual organic matter.

Earlier studies on bacteria from these tan-green mottles at 20 to $25 \mathrm{cmbsf}$ highlighted their capability of showing different phases of nitrification (Ram et al., 2001). Nitrate reduction coupled 
to oxidation of organic matter, followed by fixing of $\mathrm{CO}_{2}$ is suggestive of recycling and conservation of available organic matter. The depleted $\mathrm{NO}_{2}{ }^{-}$concentration (Fig. 3A) and its negative correlation to $\mathrm{NO}_{3}{ }^{-}$indicate coupled bacterial nitrification-denitrification process if explained traditionally. However, formation of dinitrogen and loss of nitrogen under the influence of reactive Mn (Luther III et al., 1997) can be attributed to elevated $\mathrm{C} / \mathrm{N}$ ratios at these depths. Bacterial chemo-denitrification is known to exist in oxygen containing sediments (Luther III et al., 1997). Non-steady Mn diagenesis resulting in the enrichment of Mn below these sub-oxic or tan-green transition depths has been suggested earlier in these sediments (Pattan \& Jauhari, 2001).

Organic carbon in the reactive layers (Fig. 2) stimulates oxygen consumption by active microaerophilic or facultative anaerobic bacteria (eg. nitrifiers, nitrate reducers, aerobic sulphur oxidizers and heterotrophs) during oxic respiration. This oxic process is followed by nitrate reduction within the total $6 \mathrm{~cm}$ thick overlapping reactive layers 1 and 2. Also, in these layers, manganese reduction possibly synchronizes with sulphide oxidation. Consequently, the resultant upward diffusion of dissolved metals could feed the nodule accretion process at the sediment water interface (See IVBC 20A porewater profiles in Fig. 3B).

Porewater oxygen concentrations are within ranges previously reported for the deep-sea (Jahnke \& Jahnke, 2004). Warren \& Johnson (2002) reported around 4 to $4.5 \mathrm{ml} \mathrm{l}^{-1}$ (175 to $197 \mu \mathrm{M}$ ) in waters of the northern CIB at $c a 4600 \mathrm{~m}$ below surface, along $90^{\circ} \mathrm{E}$ longitude. The convex profile of $\mathrm{NO}_{3}{ }^{-}$(Fig. 3A) is indicative of predominantly oxic conditions with net nitrification (Soetaert et al., 1996). A distinct early diagenetic reactive layer is seen at 3 to $9 \mathrm{cmbsf}$ in station TVBC 26 . The $\mathrm{PO}_{4}{ }^{3-}$ concentrations are depleted at the diagenetic reactive layer (Schulz, 2000) and within the tangreen mottled zone and are possibly related to the nitrification-denitrification coupled zones where nitrification is more prominent. The $\mathrm{SiO}_{3}{ }^{2-}$ concentration shows a typical downward increasing trend in TVBC 26 indicating a diffusive flux from the sediment water interface (Nath \& Mudholkar, 1989).

The presence of iron-bacteria and manganese-bacteria in higher numbers, along with the thiotrophs, suggests the possible occurrence of sulphide-oxidation along with iron and manganese oxido-reduction in this diagenetic setting, especially at the mottled zone. These associations are common in hydrothermally altered sediments or diffuse flow systems (Bach \& Edwards, 2003). While bacterially mediated $\mathrm{Mn}^{2+}$ oxidation by $\mathrm{O}_{2}$ or $\mathrm{NO}_{3}{ }^{-}$may be restricted near oxic zones, processes like thiotrophic nitrate reduction in deep-sea settings are gaining importance. These processes over time lead to the formation of tan green mottled zones dominated by facultative heterotrophs, manganese-oxidizers and aerobic sulphur oxidizers (Fig. 6A). These bacteria conserve 
the organic matter chemolithotrophically by recycling (Stevens, 1997) and re-fixing $\mathrm{CO}_{2}$ formed during breakdown of organic matter.

The occurrence of sulphide in some of these oligotrophic sediments highlights the greater importance of hydrothermal influence and requires renewed investigations. Although, the coexistence of sulphide and oxygen in "sub-oxic" or "oxic-anoxic" transitions are well known (Glazer et al., 2006), the trends suggest that an inverse distribution of oxygen versus sulphide in porewaters may not always be true. Co-existence of detectable amounts of sulphide, ammonium and oxygen (Fig. 3B) and the presence of manganese oxidizers and thiotrophic bacteria indicates possibility of co-occurrence (Wang et al., 2008) or overlap of multiple metabolic zones (Canfield \& Thamdrup, 2009). The present results reiterate the importance of sulphide and a possibly underestimated hydrothermal influence in the formation process of ferro-manganese nodules (cf. Glassby, 2006).

Alternatively, rock alteration and volcanic degassing could be a significant process in station TVBC 26 due to its proximity to the Trace of Rodrigues Triple Junction. Under such conditions, autotrophy at the mottled zones could be associated with fluid percolation through these sediment strata (Sizaret et al., 2009). Even then, station TVBC 26 would not be an independent chemoautotrophic system as a major fraction of the organic flux is derived from the highly productive South Equatorial Boundary Current-driven surface waters. Core TVBC 26 would be analogous to hydrocarbon rich layers mutually influenced by organic matter rain and hydrothermal fluid flow. However, the scale and extent of the processes could be highly reduced.

\section{Quantification of the influence of non-steady state diagenetic condition on microbial community by numerical simulation}

The numerical simulation (Fig. 9A), suggests the prevalence of bacterial nitrate reduction nitrite-oxidation coupling at the reactive layers. Consequently, a mottled zone forms at deeper layers and reduced metal species oxidize near the sediment-water interface. Sigmoid profiles of $\mathrm{NO}_{3}{ }^{-}$ concentration at the reactive layers are suggestive of formation and subsequent utilization of the ion at this shallow depth. The deposition of a $4 \mathrm{~cm}$ thick organic carbon-rich layer and upward migration of reduced metal species like $\mathrm{Mn}^{2+}$ leads to the coupling of nitrate reduction to nitrite oxidation. These coupled processes may reach a rate of $\pm 1000 \mu \mathrm{M} \mathrm{m}^{-3} \mathrm{yr}^{-1}$. Consequently this leads to rapid formation and removal of $\mathrm{NO}_{3}{ }^{-}$and a new nitrite oxidizing-nitrate reducing interface may be formed. This interface may potentially migrate upwards from 3 to $9 \mathrm{cmbsf}$ to the surface thus allowing manganese nodule precipitation in the form of $\mathrm{MnO}_{2}$ at the surface. The precipitation of these manganese nodules could be analogous to dolomite precipitation above sulphate-methane interfaces 
(Rao et al., 2003, Meister et al., 2007, 2009). High chemosynthetic activity has been noted in these reactive layers similar to that in sulphate methane interfaces and dolomite deposits observed at Blake Ridge (Rodriguez et al., 2000) and ODP site 1229 in the Eastern Equatorial Pacific (Meister et al., 2007). The relative compactness of porous siliceous ooze sediments at these depths (Fig. 3A) reduces permeability, partially restricting horizontal transfer and utilization of $\mathrm{NO}_{3}{ }^{-}$, in these clay-rich sediments. This results in the formation of horizontal mottled layers (Figs 2 and 3).

\section{SOUTHERN CORE TVBC 08}

\section{Influence of organic carbon on microbial carbon uptake}

The microbial autotrophic uptake profile of core TVBC 08 shows no relationship to the palaeoproductivity profile suggesting greater chemoautotrophy and independence from surface based production (Fig. 8). The depletion of organic content and the additional influence of hydrothermally derived pore-fluids appear to have triggered a greater microbial carbon uptake. A net autotrophic bacterial community with higher nitrifiers and nutritionally flexible heterotrophs inhabit the southern TOC-poor sediments of TVBC 08. These observations are further supported by a positive correlation $(\mathrm{p}>0.05)$ between ${ }^{14} \mathrm{C}$ uptake and total bacterial counts. The greater number of FDC at the TOC-depleted lower depths suggests the utilization inorganic substrates in hydrothermally altered fluids promoting greater autotrophic activity.

\section{Influence of hydrothermal alterations on porewater and bacterial activity}

Mid-plate volcanic and hydrothermally altered area, TVBC 08 (Nath et al., 2008, Iyer et al., 2007, Mascarenhas-Pereira et al., 2006) hosts a predominantly chemoautotrophic microbial population. The possibility of nitrogen species emanating out of the circulating hydrothermal fluids (Gieskes et al., 2002) and advecting upwards before spreading laterally at 4 to $8 \mathrm{cmbsf}$ (Fig. 3A) due to diffusive transport at the stratigraphic interface (Gieskes et al., 2002) is explored in the present work.

Fluid phase separation during hydrothermal alterations is known to produce higher and lower phases of solutes. While the higher phases rapidly migrate by advection towards the surface, presumably along cracks and faults, the lower ones get transported laterally along more porous zones in the sediments. Here they may get utilized by bacteria. A recent study by Nath et al. (2008) interpreted the influence of neutral chloride type hydrothermal fluids to be predominant in these altered sediments. Intense hydrothermal alteration features were reflected in 1) the depleted sedimentary organic carbon (also observed in the present study, see Fig. 2), 2) dissolution features of radiolarian skeletons, 3) the presence of altered minerals such as smectite and zeolites, and 4) 
distinctly different magnetic properties in the altered sediments. An excess of ${ }^{210} \mathrm{~Pb}$ over its parent was recorded in the lower semi-indurated sediments. Bioturbation and slumping of older sediments from the shallower portions of the seamount were ruled out for the ${ }^{210} \mathrm{~Pb}_{\mathrm{exc}}$ since the sediments lacked benthic biota, organic matter and detectable carbonate content (Nath et al., 2008).

The $\mathrm{PO}_{4}{ }^{3-}$ in TVBC 08 is lower than TVBC 26. However, the presence of a $\mathrm{PO}_{4}{ }^{3-}$ concentration $>1 \mu \mathrm{M}$ in organically depleted environments with distinct enrichment in $\mathrm{Fe}$ in an oxidized state, compared to the pelagic clays occurring in the CIB (Nath et al., 2008) indicates possible hydrothermal origin and co-precipitation with the metal oxides (Yamagata et al., 1991; Karl, 1995). The $\mathrm{SiO}_{3}{ }^{2-}$ concentrations show little variation and a lower diffusional gradient in TVBC 08.

ATP values (Fig. 5) are similar to the range reported from Guaymas Basin (Table 1). Although extensively reported from waters and bacterial mats of vent fields, reports on ${ }^{14} \mathrm{C}$ incorporation rates of whole sediments are still scanty. It is noted that ${ }^{14} \mathrm{C}$ incorporation rates (Fig. 7) of CIB sediments when normalized to bacterial numbers are similar to some water samples of Juan de Fuca and white smokers of the $21^{\circ} \mathrm{N}$ East Pacific Rise (Table 2).

The contribution of LOM and faunal number to higher measurements of ATP at TVBC 08 is minimal. Negligible numbers of macrofauna and meiofauna (Ingole et al., 2005) suggest that there could be little contribution by these organisms. Moreover, ATP does not relate to any of the other parameters measured suggesting that the higher ATP in the south could be due more to hydrothermally produced analogues rather than being organically derived (Yamagata et al., 1991; Liu et al., 1982). The high ATP in TVBC 08 (Fig. 5, Table 1) could therefore be due to the inclusion of large amounts of pyrophosphate or polyphosphates formed during rapid cooling in hydrothermal systems (Yamagata et al., 1991). The presence of Fe in an oxidized state (Nath et al., 2008) and the anomalous bulk phosphate (Nath et al., 2005) suggests scavenging of hydrothermal phosphorus by iron, leading to the formation of bio-available pyrophosphate and its subsequent utilization as an alternate pathway for channelling geothermal-based energy in the biosphere (Liu et al., 1982).

The hydrothermal origin of ammonium or other reduced nitrogenous species from deeper layers is indicated by the porewater profiles of $\mathrm{NO}_{2}{ }^{-}$and $\mathrm{NO}_{3}{ }^{-}$. Higher total nitrogen values and a $\mathrm{C} / \mathrm{N}$ ratio $<1$ at 20 to $25 \mathrm{cmbsf}$ both indicate excess of nitrogen. The high $\mathrm{C} / \mathrm{N}$ ratio and depletion of $\mathrm{NO}_{2}{ }^{-}$and $\mathrm{NO}_{3}{ }^{-}$is probably caused by the preferential loss of $\mathrm{N}$ during metamorphic volatilization (Bebout \& Fogel, 1992) at the upper stratigraphic transition between Pleistocene and Tertiary sediments (Fig. 2). Where there is minimal contribution of organic matter, this excess can only be derived from hydrothermal fluids. Similar findings have been reported from Suiyo Seamount at Izu- 
Bonin backarc system (Takano et al., 2004) and the shallow vent systems of Vulcano Islands (Gugliandolo \& Maugeri, 1998). Rapid conversion of dissolved $\mathrm{NO}_{3}{ }^{-}$and $\mathrm{NO}_{2}{ }^{-}$to $\mathrm{NH}_{4}{ }^{+}$rather than to $\mathrm{N}_{2}$, particularly in the presence of $\mathrm{Fe}$ and $\mathrm{Ni}$ as seen in ODP Leg 201 porewater data (Smirnov et al., 2008), could explain the abrubt fluctuations of nitrogen. Different transport routes for higher and lower phases of hydrothermally altered fluids while cooling can produce distinct changes both in bacterial number and activity. These alterations occur (Figs 5, 6 and 7) at sediment layers with varying porosity and $\mathrm{pH}$ (Figs 2 and 3; Gieskes et al., 2002).

The high peak of the C/N ratio with low TOC (Fig. 2) and LOM in the upper 2 to $4 \mathrm{~cm}$ bsf (Fig. 4) corresponds to the highest ATP, ammonia oxidizers and aerobic sulphur oxidizers (Figs 5 and 6). This layer is sandwiched between carbon uptake maxima (Fig. 7) suggesting chemolithotrophic utilization of inorganic substrates made available during phase separation of solutes.

Venting activities can produce ammonia where nitrifying bacteria can thrive (Karl, 1995). The higher number of autotrophic nitrifiers and the significant correlation between ammonium oxidizers and aerobic sulphur oxidizers suggests a more hydrothermal origin for the ammonium feeding the nitrite oxidizers (Karl, 1995; Wirsen et al., 1986). The presence of large numbers of thiotrophs, iron-oxidizers and manganese-oxidizers indicate that hydrothermal alterations or diffuse flow might influence the sulphide-oxidation and iron metabolism in this core (Bach \& Edwards, 2003).

Synchronization of carbohydrate maxima with the zone of high ${ }^{14} \mathrm{C}$ uptake at 15 to $20 \mathrm{~cm}$ bsf is possibly suggestive of chemoautotrophy by mixotrophs. Large fractions of heterotrophic bacteria inhabited this lower non-dateable stratigraphic transition within the Tertiary sediments. Higher adaptability and resilience of bacteria are associated with relatively oligotrophic sediments (Harder \& Dijkhuizen, 1982; Goltekar et al., 2006) like the organically depleted core TVBC 08. Similar unexplained high heterotrophic populations have been reported in some earlier findings in vent sites with low organic carbon (Karl, 1995).

Although the nitrifiers, aerobic sulphur oxidizers and heterotrophs exist in large numbers and contribute partly to ATP and ${ }^{14} \mathrm{C}$ uptake, they do not have a statistically significant relationship with the porewater nitrogen species or the $\mathrm{C} / \mathrm{N}$ ratio in TVBC 08 . This is contrary to the diagenetic TVBC 26 where these retrievable bacteria show a statistically significant relationship with other biochemical and porewater parameters. The results indicate the predominance and activity of a distinct functional group capable of exhibiting chemolithotrophy through multiple metabolic 
pathways. These microbes flourish in the remnant inorganic substrates derived from explosive hydrovolcanism that geochemists believe to have occurred about 200 years ago (Nath et al., 2008). Examining the whole community at the molecular level would complement our studies and throw more light on both their taxonomy and function.

\section{Quantification of hydrothermal alterations on porewater and microbial community by numerical simulation}

The numerical simulation (Fig. 9B), suggests the prevalence of a nitrite oxidation-nitrate reduction coupling at the Pleistocene-Tertiary stratigraphic interface due to lateral dispersion and phase separation of solute during cooling of upwelled hydrothermal fluid. Consequently, there is an enhancement of bacterial abundance and activity at the stratigraphic transition zone (Figs 5 through 7) due to the availability of inorganic substrates made utilizable by processes such as phase separation of solutes. Sigmoid profiles of $\mathrm{NO}_{3}{ }^{-}$concentration at the stratigraphic transition are suggestive of formation and subsequent utilization of the ions at this transition zone. The $6 \mathrm{~cm}$ transition zone in core TVBC 08 and upward migration of reduced chemical species from hydrothermally altered fluids leads to the coupling of nitrate reduction to nitrite oxidation. Consequently, this leads to rapid formation and removal of $\mathrm{NO}_{3}{ }^{-}$. A new nitrite oxidizing-nitrate reducing transition gets formed. The porewater $\mathrm{NO}_{2}{ }^{-}$profile would run parallel to that of $\mathrm{NO}_{3}{ }^{-}$and would not be analogous to those derived from organic matter diagenesis (eg. Core TVBC 26) when there is continuous supply. Hence, the $\mathrm{NO}_{3}{ }^{-}$profile is altered by the presence of hydrothermally derived reduced substrates.

An initial vertical focused-jet of hydrothermally altered fluid evolves into a lateral diffusion at the Pleistocene-Tertiary stratigraphic transition and allows for hydrothermal precipitation of Fe, Ti, P etc. as reported earlier by Nath et al. (2008). A negative rock alteration index (RAI) denoting precipitation (Zhao et al., 2009) may be expected at 3 to $7 \mathrm{cmbsf}$ sandwiched between positive ones denoting dissolution. Although neutral chloride type hydrothermal activity is indicated by previous studies (Nath et al., 2008), more comprehensive data on thermal and $\mathrm{Cl}^{-}$anomalies would be helpful for simulating improved models.

Variation in porosity (Fig. 3B) at the stratigraphic transition zone is sharp. The effect of advection and interactions between fluid flow, heat transfer, mass transport and chemical reactions need to be considered in a comprehensive manner using coupled transport models or finite element models (Zhao et al., 2009; Ma et al., 2006; Yang et al., 2004) taking into account the complex stratigraphic features. 


\section{CONCLUSION}

The distinctions between types of microbial autotrophic activity at different geological endmember settings are identifiable and quantifiable by multi-disciplinary approaches. Content and quality of organic matter and flow of hydrothermal heat, fluid and solutes are the most important factors controlling autotrophic activity in deep-sea sediments. The present study explores the domain of chemoautotrophy in the deep-abyssal basins of the CIB with a combination of low organic content and diffuse low temperature hydrothermal alterations.

In CIB sediments, a decrease in organic matter tends to elevate microbial carbon uptake in the bacterial communities. The northern TVBC 26 is predominantly heterotrophic with chemosynthetic signatures at the tan-green mottled zones. The bacterial activity is only partially dependent on the surface productivity at core TVBC 26. The depth of reactive layers and tan-green mottled zones coincides with high chemosynthetic activity and low palaeosurface productivity. The autotrophy prevailing in the tan-green transition is analogous to the organic matter fossilization and hydrocarbon formation in organic rich sedimentary settings (Ma et al., 2006; Campbell, 2006; Mazumdar et al., 2009).

The southern TVBC 08 is predominantly autotrophic with heterotrophic microbial signatures in the deeper layers. Here chemoautotrophy is totally independent of surface productivity. The heterotrophy in the deeper parts of southern core TVBC 08 is possibly akin to the formation of new degradable organic compounds in hydrothermal settings. This system is possibly analogous to settings like the Loihi Seamount. Further study of this location may provide interesting insights into tracing pre-biotic origins and explorations for lunar, martian or jovian planetary systems (Goodman et al., 2004).

The role of thiotrophs in deep-sea sediments is prominent in both diagenetic and hydrothermally altered sediments. Processes like thiotrophic nitrate reduction may be more influential in the northern TOC and sulphide-rich sediments. The data highlights the necessity of renewed investigations involving porewater $\mathrm{NH}_{4}{ }^{+}, \mathrm{HS}^{-}, \mathrm{Mn}$ and $\mathrm{Fe}$ in oxic conditions. Thiotrophs in hydrothermally altered sediments or diffuse flow systems might be influencing sulphide-oxidation and iron metabolism. The presence of large numbers of iron-oxidizers, manganese-oxidizers and thiotrophs at the mottled zones of TVBC 26 and in hydrothermally altered core TVBC 08 indicate their close relationship to rock alteration and mineralization processes.

These findings could stimulate the pursuit of chemosynthesis for sequestering $\mathrm{CO}_{2}$ in the deep sea floor. The present study also adds a theoretical dimension for expanding the potential for 
hydrocarbon exploration in the ocean as discussed earlier in the Pacific nodule province by Wenxuan et al. (2002). In these stretches of metal-rich oligotrophic abyssal sediments, hydrothermal activities may predominate, at least over a 100 to 1000 year time scale and require further quantification. However, hydrothermal activity and associated rock alteration processes may be more relevant than organic matter delivery in these deep-sea sediments.

\section{ACKNOWLEDGEMENTS}

The authors are grateful to S.R. Shetye, Director, National Institute of Oceanography for his encouragement. V. Subramaniam and M-J. B.D. De Souza helped with the microbial ${ }^{14} \mathrm{C}$ uptake analyses. J.N. Pattan, K.P. Krishnan and Siby Kurien are acknowledged for their help during the course of the work. V. Nanjundaiah (IISc, India), Deiter Wolf-Gladrow (AWI, Germany), D. Shankar, A. Mazumdar and N.T. Manoj introduced AD to the field of numerical simulations and codes, conceptual biogeochemical and biological modeling. Facilitation on-board by the shipboard scientific party and crew of Akademik Alexandr Sidorenko (Cruise 61, 2003), Akademik Boris Petrov (Cruise 4, 2005) and Akademik Boris Petrov (Cruise 38, 2009) is acknowledged. Special thanks are due to Patrick Meister (ETH-Zürich/Bremen University) and other anonymous reviewer(s) for their critical guidance leading to significant improvement in the manuscript. This work was financially supported by the Ministry of Earth Sciences, Government of India. AD, CEGF and SPP acknowledge Council of Scientific and Industrial Research (CSIR), New Delhi for funding their research work. This paper is NIO's contribution no. XXXXXX.

\section{REFERENCES}

Aldrich, A.P. and van der Berg, C. M. G. (1998) Determination of Fe and its redox speciation in seawater using catalytic cathodic stripping voltametry. Electroanal, 10(6) 369-373.

ASTM, (1995). Annual book of ASTM Standards, 04.08. Soil and Rocks (I) D420-D4914, ASTM, Philadelphia, USA, pp. 981.

Bach, W. and Edwards, K. (2003) Iron and sulphide oxidation within the basaltic ocean crust: Implications for chemolithoautotrophic microbial biomass production. Geochim Cosmochim Acta, 67(20), pp. 3871-3887.

Banakar, V.K., Gupta, S.M. and Padmavathi, V.K. (1991) Abyssal sediment erosion in the Central Indian Basin: Evidence from radiochemical and radiolarian studies. Mar.Geol. 96, 167-173.

Borole, D.V. (1993) Late Pleistocene sedimentation: A case study of the Central Indian Ocean Basin. Deep-Sea Res., 40(4), 761-775. 
Bebout G. E., and Fogel M. L. (1992) Nitrogen-isotope compositions of metasedimentary rocks in the Catalina Schist, California: Implications for metamorphic devolatilization history. Geochim. Cosmochim. Acta, 56, 2839-2849.

Bligh, E.G. and Dyer, W.J. (1959) A rapid method of total lipid extraction and purification. Can. J. Biochem. Physiol. 37, 911-917.

Buckley, D.E. and Cranston, R. E. (1988) Early diagenesis in deep sea turbidites: The imprint of palaeo-oxidation zones Geochim. Cosmochim. Acta., 52, 2925-2939.

Cauwet, G. (1978) Organic chemistry of seawater particulates: Concepts and developments. Oceanologica Acta, 1, 99-105.

Campbell, K. A. (2006), Hydrocarbon seep and hydrothermal vent paleoenvironments and paleontology: Past developmentsand future research directions. Palaeogeogr. Palaeoclimatol. Palaeoecol., 232, 362 - 407, doi:10.1016/ j.palaeo.2005.06.018.

Canfield, D. E. (1991), Sulfate reduction in deep sea sediments, Am. J. Sci., 291, 177-188.

Canfield D.E., Thamdrup, B. (2009) Towards a consistent classification scheme for geochemical environments, or, why we wish the term 'suboxic' would go away. Geobiol, 7, 385-392.

Chase, R.L., Delaney, J.R., Karsten, J.L., Johnson, H.P., Juniper, S.K., Lupton, J.E., Scott, S.D., Tunnicliffe, V., Hammond, S.R. and McDuff, R.E. (1985) Hydrothermal vents on an axis seamount of the Juan de Fuca ridge. Nature, 313, 212-214.

Chevaldonne, P., Desbruyeres, D. and Le Haitre, M. (1991). Time-series of temperature from three deep-sea hydrothermal vent sites. Deep Sea Res. A 38, 1417-1430.

Childress, J. J., Fisher, C. R., Favuzzi, J. A., Kochevar, R. E., Sanders, N.K. and Alayse, A. M. (1991) Sulphide-driven autotrophic balance in the bacterial symbiont-containing hydrothermal vent tubeworm Riftia pachyptila. Biol. Bull., 180, 135-153.

Colley, S. and Thomas, J. (1985) Recurrent uranium relocations in distal turbidites emplaced in pelagic conditions. Geochim. Cosmochim.Acta 49.2339-2348.

Colley S., Thomson J., Wilson; T. R. S. and Higgs N. C. (1984) Post depositional migration of elements during diagenesis in brown clay and turbidite sequences in the North East Atlantic. Geochim.Cosmochim. Acta, 48, 1223- 1235.

Colombini, M.P. and Fuocco, R. (1983) Determination of manganese at $\mathrm{ng} / \mathrm{ml}$ levels in natural water by differential pulse polarography. Talanta, 30(12), 901-905.

Delistraty, D.A. and Hershner, C. (1983) Determination of adenine nucleotide levels in Zostera marina (eelgrass). J. Appl. Biochem., 5, 404-405.

Das, P., Iyer, S.D., and Kodagali, V.N. (2007) Morphological characteristics and emplacement mechanism of the seamounts in the Central Indian Ocean Basin. Tectonophysics, 443, 1-18.

D’Hondt, S., Rutherford, S. and Spivack, A.J. (2002) Metabolic activity of sub-surface life in Deep-Sea. Science, 295, 2067-2070. 
D’Hondt, S., Jørgensen, B.B., Miller, D. J. Batzke, A., Blake, R., Cragg, B.A., Cypionka, H. Dickens, G.R., Ferdelman, T., Kai-Uwe Hinrichs, K.-U., Holm, N.G., Mitterer, R., Spivack, A., Wang, G., Bekins, B., Engelen, B., Ford, K., Gettemy, G., Rutherford, S. D., Sass, H., Skilbeck, C.G., Aiello, I.W., Gue`rin, G. Christopher H. House, C.H., Inagaki, F., Meister, P., Naehr,T., Niitsuma, S., Parkes, R.J., Schippers, A. Smith, D.C., Teske, A., Wiegel, J., Padilla, C. N., Juana Luz Solis Acosta, J.L.S, (2004) Distributions of microbial activities in deep subseafloor sediments Science, 306, 2216-2221.

Ehrlich, H.L. (1998) Geomicrobiology: its significance for geology. Earth-Sci. Rev., 45, 45-60.

Edwards, K. J., Bach, W. and McCollom, T.M. (2004) Neutrophilic Iron-Oxidizing Bacteria in the Ocean: Their Habitats, Diversity, and Roles in Mineral Deposition, Rock Alteration, and Biomass Production in the Deep-Sea. Geomicrobiol. J., 21, 393-404.

Farrimond P., Eglinton G., Brassell S.C. and Jenkyns H.C. (1989) Toarcian anoxic event in Europe an organic geochemical study. Mar.Petrol. Geol., 6, 136-147.

Fichez, R. (1991) Composition and fate of organic matter in submarine cave sediments: implications for the biogeochemical cycle of organic carbon. Oceanol. Acta., 14, 369-377.

Folk, R.L. 1968. Petrology of sedimentary rocks. Univ. Texas, Austin, Texas, pp. 170.

Froelich, P.N., Klinkhammer, G.P., Bender, M.L., Luedtke, G.R., Heath, G.R., Cullen, D., Dauphin, P., Hammond, D., Hartman, B. and Maynard, V. (1979) Early oxidation of organic matter in pelagic sediments of the eastern equatorial Atlantic: Sub-oxic diagenesis. Geochim. Cosmochim. Acta., 43, 1075-1090.

Gieskes, J.M., Simoneit, B. R.T., Goodfellow, W.D., Baker, P.A. and Mahn, C. (2002) Hydrothermal geochemistry of sediments and porewaters in Escanaba Trough-ODP Leg 169. Appl Geochem., 17, 1435-1456.

Ghosh, A.K. and Mukhopadhyay, R. (1999) Exploration. In: Mineral wealth of the Ocean. Oxford and IBH Publishing Co. Pvt. Ltd. pp. 176-203.

Glasby, G. P. (2006) Manganese: Predominant role of nodules and crusts, In: Marine Geochemistry, edited by H. D. Schulz and M. Zabel, pp. 371-428, Springer, Berlin.

Glazer, B.T., Luther III,G.W., Konovalov, S. K., Friederich, G.E., Trouwborst, R.E. and Romanov, A.S. (2006) Spatial and temporal variability of the Black Sea suboxic zone. DeepSea Res II, 53, 1756-1768.

Goltekar, R.C., Krishnan, K.P., DeSouza, M.J.B.D., Paropkari, A.L. and Loka Bharathi, P.A. (2006) Effect of carbon source concentration and culture duration on retrievability of bacteria from certain estuarine, coastal and offshore areas around peninsular India. Curr. Sci., 90(1), 103-106.

Goodman, J. C., Collins, G. C. Marshall, J. and Pierrehumbert, R. T. (2004) Hydrothermal plume dynamics on Europa:Implications for chaos formation, J. Geophys. Res., 109, E03008, doi:10.1029/2003JE002073.

Grasshoff, K., Ehrhardt, M., and Kremling, K. (1983) Methods of seawater analysis (2nd ed.). Verlag Chemie, 419 pp. 
Gugliandolo, C. and Maugeri, T.L.(1998) Temporal Variations in Heterotrophic Mesophilic Bacteria from a Marine Shallow Hydrothermal Vent off the Island of Vulcano (Eolian Islands, Italy). Microb Ecol., 36, 13-22.

Gupta, S.M., (1991a) Radiolarian zonation and volcanic ash-layers in two sediment cores from the Central Indian Basin. Jour. Paleontol. Society of India, 33, 59-71.

Gupta, S.M., (1991b) New ichthyoliths from ferromanganese crusts and nodules from the Central Indian Ocean Basin. Micropaleontology 37, 125-147.

Gupta, S.M. and Jauhari, P. (1994) Radiolarian abundance and geochemistry of the surface sediments from the Central Indian Basin. Curr. Sc., 66(9), 659-663.

Haberstroh, P.R. and Karl, D.M. (1989) Dissolved free amino acids in hydrothermal vent habitats of the Guaymas Basin. Geochim. Cosmochim. Acta, 53, 2937-2945.

Hagstrom, A., Larsson, U., Horstedt, P. and Normark S. (1979) Frequency of dividing cells, a new approach to the determination of bacterial growth rates in aquatic environments. Appl. Environ. Microbiol., 37(5), 805-812.

Harder, W. and Dijkhuizen, L. (1982) Strategies of mixed substrate utilization in microorganisms. Philos. Trans. R. Soc. London. B., 297, 459-480.

Havert, H.H. (1992) Genus Siderocapsa (and other Iron or Manganese-oxidizing Eubacteria). In : The prokaryotes $-A$ handbook on the biology of bacteria, ecophysiology, isolation, identification and applications. Eds. Balows, A., Trüper, H.G., Dworkin, M.,Harder, W., Schleifer, K.-H. Vol IV. Springer-Verlag, pp 4102-4113.

Hobbie, J.E., Daley, R.J. and Jasper, S. (1977) Use of Nucleopore filters for counting bacteria by fluorescent microscopy. Appl Environ. Microbiol., 3, 1225-1228.

Holm-Hansen, O. and Booth, C. R. (1966) The measurement of adenosine triphosphate in the ocean and its ecological significance. Limnol. Oceanogr., 11, 510-519.

Ingole, B.S., Pavitran, S., Goltekar, R. and Gonsalves, S. (2005) Faunal diversity and abundance. In: Benthic environmental variability in the Central Indian Ocean Basin-I. Project report submitted to Department of Ocean Development, Govt. of India.

Iyer, S.D., Mascarenhas-Pereira, M.B.L. and Nath B.N. (2007) Native aluminium (spherules and particles) in the Central Indian Basin sediments: Implications on the occurrence of hydrothermal events. Mar. Geol., 240, 177-184.

Jahnke, R.A. and Jahnke, D.B. (2004) Calcium carbonate dissolution in deep sea sediments: Reconciling microelectrode, porewater and benthic flux chamber results. Geochim Cosmochim Acta, 68(1), 47-59.

Johnson, D.A., Schneider, D.A., Nigrini, C.A., Caulet, J.P. and Kent, D.V. (1989) PliocenePleistocene radiolarian events and magnetostratigraphic calibrations for the Tropical Indian Ocean. Mar. Micropaleontol. 14, 33-66.

Joux, F. and Lebaron, P. (1997) Ecological implications of an improved Direct Viable Count Method for Aquatic Bacteria. Appl. Environ. Microbiol., 63(9), 3643-3647. 
Kamesh Raju, K.A. and Ramprasad, T. (1989) Magnetic lineations in the Central Indian Basin for the period A24-A21: a study in relation to the Indian Ocean Triple Junction trace. Earth Planet. Sc. Letts., 95, 3-4, 395-402.

Karl, D.M., Brittain, A.M. and Tilbrook, B.D. (1989) Hydrothermal and microbial processes at Loihi seamount, a mid plate hot-spot volcano. Deep-Sea Res., 36, 1655-1673.

Karl, D.M. (1995) Ecology of free-living, hydrothermal vent microbial communities. In: The microbiology of deep-sea hydrothermal vents (ed Karl, D.M.). CRC press. pp 35-124.

Kochert, G. (1978) Carbohydrate determined by the phenol-sulfuric acid method. In: Handbook of physiological methods: Physiological and biochemical methods. (Eds JA Hellebust and J J Craigie). Cambridge University Press, Cambridge. pp. 95-97.

Kogure, K., Simidu, U. and Taga, N. (1984) An improved direct viable count method for aquatic bacteria. Arch. Hydrobiol.., 102, 117-122.

Konig, I., Drodt, M., Suess, E. and Trautwein, A.X. (1997) Iron reduction through the tan-green color transition in deep-sea sediments. Geochim. Cosmochim. Acta. 61 (8), 1679-1683.

Krishnaswami, S. and Sarin, M.M., (1976). The simultaneous determination of $\mathrm{Th}, \mathrm{Pu}, \mathrm{Ra}$ isotopes, ${ }^{210} \mathrm{~Pb},{ }^{55} \mathrm{Fe},{ }^{32} \mathrm{Si}$ and ${ }^{14} \mathrm{C}$ in marine suspended phases. Anal. Chim. Acta 83, 143-156.

Liu, C-L, Hart, N., Peck and Jr, H.D. (1982) Inorganic pyrophosphate: energy source for sulfatereducing bacteria of the genus Desulfotomaculum. Science, 217, 363-364.

Lochte, K., Boetius, A. and Petry, C. (2000) Microbial food webs under severe nutrient limitations: life in the deep sea. In: Bell, C.R., Brylinsky, M., Johnson-Green, P. (eds.) Microbial Biosystems: New Frontiers. Proceedings of the 8th International Symposium on Microbial Ecology. Atlantic Canada Society for Microbial Ecology, Halifax, Canada. pp. 95-102.

Loka Bharathi, P.A., Pradeep Ram, A.S., Nair, S., Nath, B.N. and Chandramohan, D. (2004) Distribution of baroduric, psychrotrophic and culturable nitrifying and denitrifying bacteria in the Central Indian Basin. Proc. Natl. Seminar on New Frontiers in Mar. Biosci. Res., 319330.

Loka Bharathi, P.A., De Souza, M.J.B.D., Nair, S. and Chandramohan, D. (1999) Abundance, Viability and Culturability of Antarctic Bacteria. Fifteenth Indian Expedition to Antarctica, Scientific Report. Dept. of Ocean Development, Technical Publication No. 13, 79-92.

Loka Bharathi, P.A. and Chandramohan, D. (1990) Sulfate-reducing bacteria from the Arabian Sea- their distribution in relation to thio-sulfate oxidizing and heterotrophic bacteria. Bull Mar Sc., 47 (3), 622-630.

Loka Bharathi, P.A. (1989) The occurrence of denitrifying colourless sulphur-oxidizing bacteria in marine waters and sediments as shown by the agar shake technique. FEMS Microbiol Ecol. 62, 335-342.

Lowry, O.H., Rosebrough, N.J., Farr, A.L. and Randall, R.J. (1951) Protein measurement with the Folin-Phenol reagents. J. Biol. Chem., 193, 265-275. 
Luther III, G.W., Sundby Bjørn, Lewis L. Brent, Brendel P.J., and Silverberg, N. (1997) Interactions of manganese with the nitrogen cycle: Alternative pathways to dinitrogen. Geochim Cosmochim Acta 61(19), 4043-4052.

Lyle, M. (1983) The brown-green colour transition in marine sediments: A marker of Fe(III)-Fe(II) redox boundary. Limnol. Oceanogr., 28(5), 1026-1033.

Ma, F., Al-Aasm, I. and Yang, J. (2006) Numerical modeling of hydrothermal fluid flow coupled with mass transport: An example from the Devonian Wabamun Group, northeast British Columbia, Canada. J. Geochem. Explor. 89, 247-250.

Mascarenhas-Pereira, M.B.L., Nath, B.N., Borole, D.V. and Gupta, S.M. (2006) Nature, source and composition of volcanic ash in sediments from a fracture zone trace of Rodriguez Triple Junction in the Central Indian Basin. Mar Geol., 229(1), 79-90.

Matondkar, S.G.P., Nair, K.K.C. and Ansari, Z.A. (2005) Biological characteristics of Central Indian Basin Water during the Southern Summer. Mar. Geores. Geotechnol., 23(4), 299-314.

Mazumdar, A., Dewangan, P., Joäo, H. M., Peketi, A., Khosla, V. R., Kocherla, M., Badesab, F. K., Joshi, R. K., Roxanne, P., Ramamurty, P. B., Karisiddaiah, S. M., Patil, D. J., Dayal, A. M., Ramprasad, T., Hawkesworth C. J. and Avanzinelli R. (2009). Evidence of paleocold seep activity from the Bay of Bengal, offshore India, Geochem.Geophys. Geosyst., 10(6), Q06005, doi:10.1029/2008GC002337.

Meister, P., McKenzie, J.A., Vasconcelos, C., Frank, M. and Gutjahr, M. (2007) Dolomite formation in the dynamic deep biosphere: results from the Peru margin (ODP Leg 201). Sedimentology, 54, 1007-1032.

Meister, P., Bernasconi, S.M., Aiello, I.W., Vasconcelos, C. and Mckenzie, J. A. (2009) Depth and controls of Ca-rhodochrosite precipitation in bioturbated sediments of the Eastern Equatorial Pacific, ODP Leg 201, Site 1226 and DSDP Leg 68, Site 503 Sedimentology doi: 10.1111/j1365-3091.2008.01046.x.

Mukhopadhyay, R., Iyer, S.D. and Ghosh, A.K. (2002) The Indian Ocean Nodule Field: Petrotectonic Evolution and Ferromanganese Nodules. Earth Sc. Rev., 60, 67-130.

Naganuma, T., Otsuki, A. and Seki, H. (1989) Abundance and growth rate of bacterioplankton community in hydrothermal vent plumes of the North Fiji Basin. Deep-sea Res., 36, 13791390.

Nath, B.N. and Mudholkar, A.V. (1989) Early diagenetic processes affecting nutrients in the porewaters of Central Indian Ocean cores. Mar.Geol., 86, 57-66.

Nath, B.N., Rao, V.P. and Becker, K.P. (1989) Geochemical evidence of terrigenous influence in deep-sea sediments upto $8^{\circ} \mathrm{S}$ in the Central Indian Basin. Mar. Geol., 87, 301-313.

Nath, B.N., Roelandts, I., Sudhakar, M. and Plüger, W.I. (1992) Rare earth element patterns of the Central Indian Basin sediments related to their lithology. Geophys. Res. Lett., 19(12), 1197-1200. 
Nath, B.N., Bau, M., Rao, B.R. and Rao, Ch.M. (1997) Trace and rare earth elemental variation in Arabian Sea sediments through a transect across the oxygen minimum zone. Geochim. Cosmochim. Acta: 61(12); 1997; 2375-2388.

Nath, B.N., Mascarenhas-Pereira, M.B.L., Kurien, S., Selvaraj, K., Naman, D., Desai, N., D'souza, V. and Naik, T. (2005) Porewater nutrients and sediment chemistry. In: Benthic environmental variability in the Central Indian Ocean Basin-I. Project report submitted to Department of Ocean Development, Govt. of India.

Nath, B.N., Borole, D. V. Aldahan, A. Patil, S. K, Mascarenhas-Pereira M. B. L., Possnert, Ericsson, G., T., Ramaswamy, V., and Gupta, S. M. $(2008){ }^{210} \mathrm{~Pb},{ }^{230} \mathrm{Th}$, and ${ }^{10} \mathrm{Be}$ in Central Indian Basin seamount sediments: Signatures of degassing and hydrothermal alteration of recent origin, Geophys. Res. Lett., 35, L09603.

Nelson, D.C., Wirsen, C.O. and Jannasch, H.W. (1989) Characterization of large, autotrophic Beggiatoa spp. abundant at hydrothermal vents of the Guaymas basin. Appl. Environ. Microbiol., 55, 2909-2917.

Pachmayr, F. (1960) Vorkommen und Bestimmug Von Schwefelverbindungen in Mineralwasser. Diss, Univ. Munchen, 48pp.

Pai, S.C., Gong, G.C. and Liu, K.K. (1993) Determination of dissolved oxygen in seawater by direct spectrophotometry of total iodine. Mar Chem 41, 343-351.

Parkes, R.J., Webster, G., Cragg, B. A., Weightman, A.J., Newberry, C.J., Ferdelman, T.G., Kallmeyer, J., Bo Jørgensen, B., Ivano W. Aiello, I.W. and Fry, J.C. (2005) Deep subseafloor prokaryotes stimulated at interfaces over geological time. Nature 436, 390-394.

Patience, R.L., Clayton, C.J., Kearsley, A.T., Rowland, S.J., Bishop, A.N., Rees, A.W.G., Bibby, K.G., and Hopper, A.C. (1990). An integrated biochemical, geochemical, and sedimentological study of organic diagenesis in sediments from Leg 112. In Suess, E., von Huene, R., et al., Proc. ODP, Sci. Results, 112: College Station, TX (Ocean Drilling Program), 135-153. doi:10.2973/odp.proc.sr.112.191.1990

Pattan, J. N., Masuzawa, T., Borole, D. V., Parthiban, G., Jauhari, P. and Yamamoto, M., (2005) Biological productivity, terrigenous in ${ }^{\circ}$ uence and noncrustal elements supply to the Central Indian Ocean Basin: Paleoceanography during the past ca 1 Ma. J. Earth Syst. Sci., 114(1), 63-74.

Pattan, J.N. and Jauhari, P. (2001) Major, Trace, and Rare Earth Elements in the Sediments of the Central Indian Ocean Basin:Their Source and Distribution. Mar. Geores. Geotechnol., 19, 85-106.

Ram, A.S.P., Loka Bharathi, P.A., Nair, S. and Chandramohan, D. (2001) A deep-sea bacterium with unique nitrifying property. Curr Sc., 80(9), 1222-1224.

Rao, V.P. and Nath, B.N. (1988) Nature, distribution and origin of clay minerals in grain size fractions of sediments from Manganese Nodule Field, Central Indian Ocean Basin. Ind. J. Mar. Sc., 17, 202-207. 
Rao, V.P., Kessarkar, P.M., Krumbein, W.E., Krajewski, K.P. and Schneiders, R.J. (2003) Microbial dolomite crusts from the carbonate platform of western India. Sedimentology 50, 819-830.

Rodina, A.G. (1972) Methods of culturing iron bacteria In: Methods in aquatic microbiolog.y Eds. Colwell, R.R.and Zambruski, M.S. Univ. Park Press, Baltimore, USA, pp 358-367.

Rodriguez, N.M., Paull, C.K. and Borowski, W.S. (2000) Zonation of authigenic carbonates within gas hydrate-bearing sedimentary sections on the Blake Ridge: offshore southeastern North America. In: Proc. ODP, Sci. Results (Eds C.K. Paull, R. Matsumoto, P.J. Wallace and W.P. Dillon), 164, 301-312. Ocean Drilling Program, College Station, TX.

Schenau, S.J., Slomp, C.P. and De Lange G.-J. (2000) Phophogenesis and active phosphorite formations in sediments from Arabian Sea oxygen minimum zone. Mar Geol 169 1-20.

Schulz, H.D. (2000) Quantification of Early Diagenesis: Dissolved constituents in Marine porewater. In: Marine Geochemistry (Eds. H.D. Schulz and M. Zabel) Spriger Verlag, Berlin-Heidelberg, pp. 87-122.

Sizaret, S., Branquet, Y.,Gloaguen, E., Chauvet, A., Barbanson, L., Arbaret, L., and Chen, Y. (2009). Estimating the local paleo-fluid flow velocity: New textural method and application to metasomatism Earth Planet Sci Lett 280 71-82.

Soetaert, K., Herman, P.M.J. and Middelburg, J.J. (1996) A model of early diagenetic processes from the shelf to abyssal depths. Geochim. Cosmochim Acta 60(6), 1019-1040.

Stevens, T. (1997) Lithoautotrophy in the subsurface. FEMS Microbiol. Rev., 20, 327-337.

Stein, R. (1991) Accumulation of organic carbon in marine sediment. Lect. Notes Earth Science, 34, $1-217$.

Suess, E., Muller, P.J., Powell, H.S. and Reimers, C.E. (1980) A closer look at nitrification in pelagic sediments. Geochem. J., 14, 129-137.

Schulz, H.N. and Schulz, H.D. (2005) Large sulfur bacteria and the formation of phosphorite 307, 416-418.

Takano, Y., Kobayashi, K., Yamanaka, T., Marumo, K. and Urabe T. (2004) Amino acids in the $308^{\circ} \mathrm{C}$ deep-sea hydrothermal system of the Suiyo Seamount, Izu-Bonin Arc, Pacific Ocean. Earth Planetary Sc. Letts., 219, 147-153.

Teske AP (2004) The deep subsurface biosphere is alive and well. Trends Microbiol 13, 402-404.

Tuttle, J.H. and Jannasch, H.W. (1977) Thiosulfate stimulation of microbial dark assimilation of carbon dioxide in shallow marine waters. Microb. Ecol., 4, 9-25.

Van Es, F.B. and Meyer-Reil, L.-A. (1982) Biomass and metabolic activity of heterotrophic marine bacteria. In: Advances in microbial ecology (ed. Marshal, K.C.). Plenum Press, New York, 6,111-170. 
Wang, G., Spivack, A. J., Rutherford, S., Manor, U. and D'Hondt, S. (2008) Quantification of co-occurring reaction rates in deep subseafloor sediments. Geochim et Cosmochim Acta $\mathbf{7 2}$, 3479-3488.

Ward, B.B, Kilpatrick, K.A., Renger, E.H. and Eppley, R.W. (1989) Biological nitrogen cycling in the nitracline. Limnol Oceanogr 34(3), 493-513.

Warren, B.A., (1982). The deep water of the Central Indian Basin. Journal of Marine Research 40 (Suppl.), 823-860.

Warren, B.A. and Johnson, G.C. (2002) The overflows across the Ninetyeast Ridge. Deep-Sea Res II 49, 1423-1439.

Wenbo, S., Yongbiao, W., Cramer, B.D., Munnecke, A., Zhiming, I. and Lipu, F. (2008) Preliminary Estimation of Paleoproductivity via TOC and Habitat Types: Which Method Is More Reliable? - A Case Study on the Ordovician-Silurian Transitional Black Shales of the Upper Yangtze Platform, South China. J China University of Geosciences, 19(5), 534-548.

Wenxuan, H., Zhijun,J., Suping, Y., Xiancai, L., Zhilin, C., Linye, Z.,Xuejun, Z., and Huaiyang, Z.,(2000) Discovery of low-mature hydrocarbon in manganese nodules and ooze from the Central Pacific deep sea floor. Chinese Sci. Bull. 47 (11) 939-944.

Wirsen, C.O., Tuttle, J.H. and Jannasch, H.W. (1986) Activities of sulfur-oxidizing bacteria at the $21^{\circ} \mathrm{N}$ East Pacific Rise Vent site. Mar. Biol., 92, 449-456.

Yamagata, Y., Watanabe, H., Saitoh, M. and Namba, T. (1991) Volcanic production of polyphosphates and its relevance to prebiotic evolution. Nature, 352, 516-519.

Yang, J., Bull, S. and Large, R. (2004) Numerical investigation of salinity in controlling oreforming fluid transport in sedimentary basins: example of the HYC deposit,Northern Australia. Mineral Deposit 39, 622-631.

Zervas, D., Nichols, G.J. Hall, R.., Smyth, H.R., Charlotta Lüthje and Murtagh, F. (2009) SedLog: A shareware program for drawing graphic logs and log data manipulation Computer Geosci 35, 2151-2159.

Zhao, C., Hobbs, B.E. and Ord, A. (2009) Theoretical and Numerical Investigation into Roles of Geofluid Flow in Ore Forming Systems: Integrated Mass Conservation and Generic Model Approach. J. Geochem. Explor. doi:10.1016/j.gexplo.2009.11.005.

ZoBell, C.E. (1941) The cultural requirements of heterotrophic aerobes. J. Mar. Res., 4, 42-75. 


\section{Captions for tables:}

Table 1. Comparison of ATP values of other established vent fields to CIB stations.

Table 2. Comparison of ${ }^{14} \mathrm{C}$ incorporation values of other established vent fields to CIB stations. 


\section{Captions for figures:}

Fig. 1. Area map modified from Mascarenhas-Pereira et al., 2006.

A. Station locations with bathymetric and sediment types marked 1 to 5

B. Station locations according to topographic features.

Fig. 2. Age, biostratigraphy, lithology, elemental carbon and nitrogen profiles of TVBC 26 and TVBC 08 (data points on y-axis suggest values below detection limit).

Fig. 3 A. Porewater profiles of $\mathrm{NO}_{2}{ }^{-}, \mathrm{NO}_{3}{ }^{-}, \mathrm{PO}_{4}{ }^{3-}, \mathrm{SiO}_{3}{ }^{2-}, \mathrm{pH}$ and porosity (data points on y-axis suggest values below detection limit).

Fig. 3 B. Porewater $\mathrm{O}_{2}, \mathrm{Mn}, \mathrm{Fe}, \mathrm{NH}_{4}{ }^{+}$and $\mathrm{HS}^{-}$of core IVBC $20 \mathrm{~A}$ in the vicinity of TVBC 26 (data points on y-axis suggest values below detection limit).

Fig. 4. Biochemical parameters per gram dry sediment (error bars represent sample ranges at individual depths).

Fig. 5. Bacterial counts and ATP content per gram dry sediment (error bars represent range for samples at individual depths).

Fig. 6A. Culturable bacteria per gram dry sediment in core TVBC 26.

Fig. 6B. Culturable bacteria per gram dry sediment in core TVBC 08 (data points on y-axis suggest very low culturability; narrow range of less than $\pm 0.01 \%$ variation for individual samples does not appear on this scale). 
Fig. 7. Microbial carbon uptake by sediments of TVBC 26 and TVBC 08 expressed in nmol $\mathrm{C} \mathrm{g}^{-1}$ dry sediment day ${ }^{-1}$ Insets show background values representing heat killed controls and experimental C uptake.

Fig. 8. Comparative profiles of palaeoproductivity and modern autotrophic carbon uptake with respect to geochemical boundaries in the radiometrically determined late Pleistocene-Holocene time scale.

Fig. 9 Numerical simulations

A. Core TVBC 26. Simulation of non-steady state of $\mathrm{NO}_{3}{ }^{-}$concentrations in porewater due to diffusion, production and consumption, showing the prevalence of a nitrification-denitrification coupling at 3 to $9 \mathrm{~cm}$ bsf.

B. Core TVBC 08. Simulation of hydrothermal alteration of porewater $\mathrm{NO}_{3}{ }^{-}$concentrations affected by production, upward diffusion, dispersion due to phase change and consumption by microbes showing the existence of nitrification-denitrification couple at 3 to $9 \mathrm{~cm}$ bsf. 

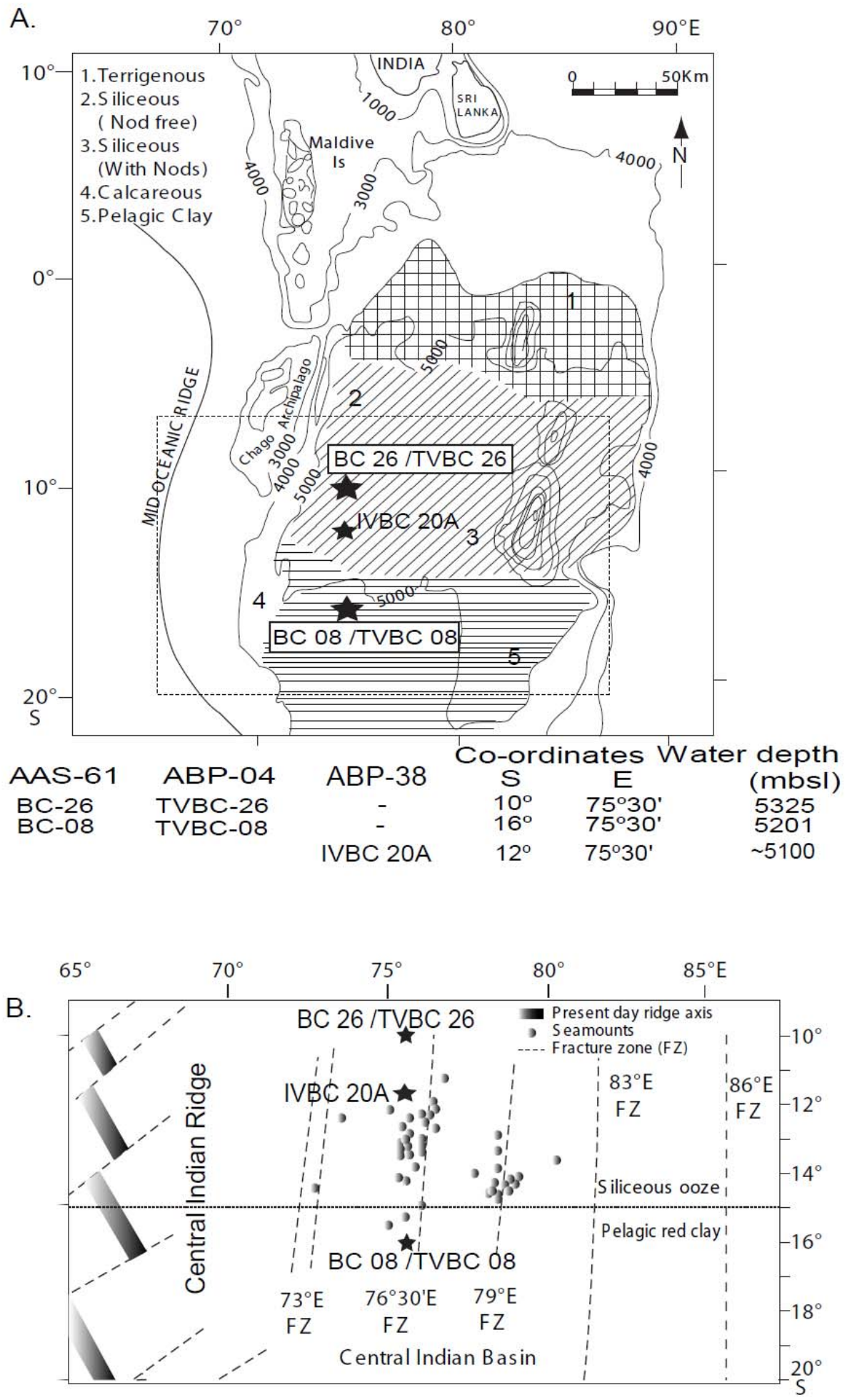

Fig.1. Das et al, 2010. 


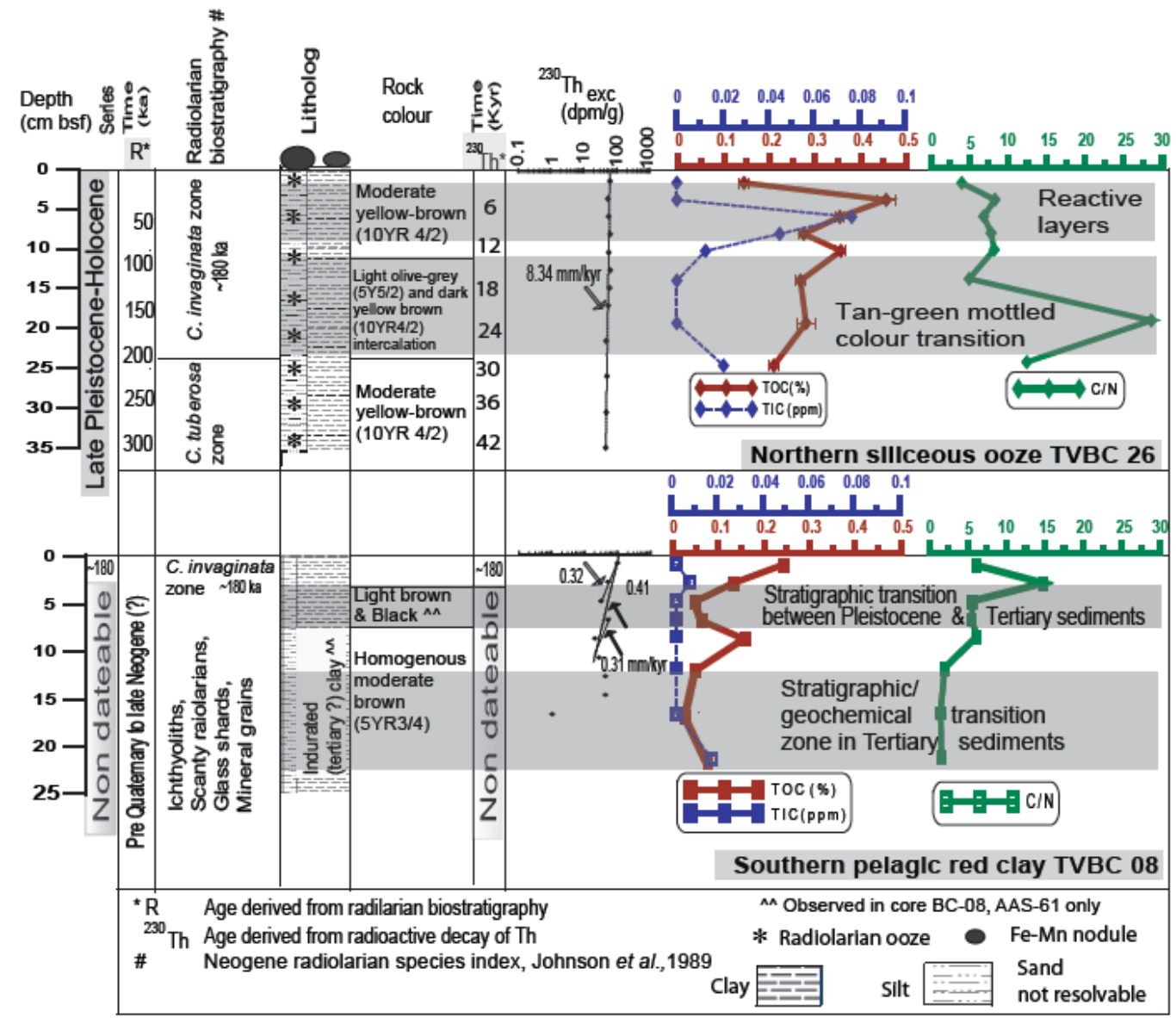

Fig. 2. Das et al., 2010 


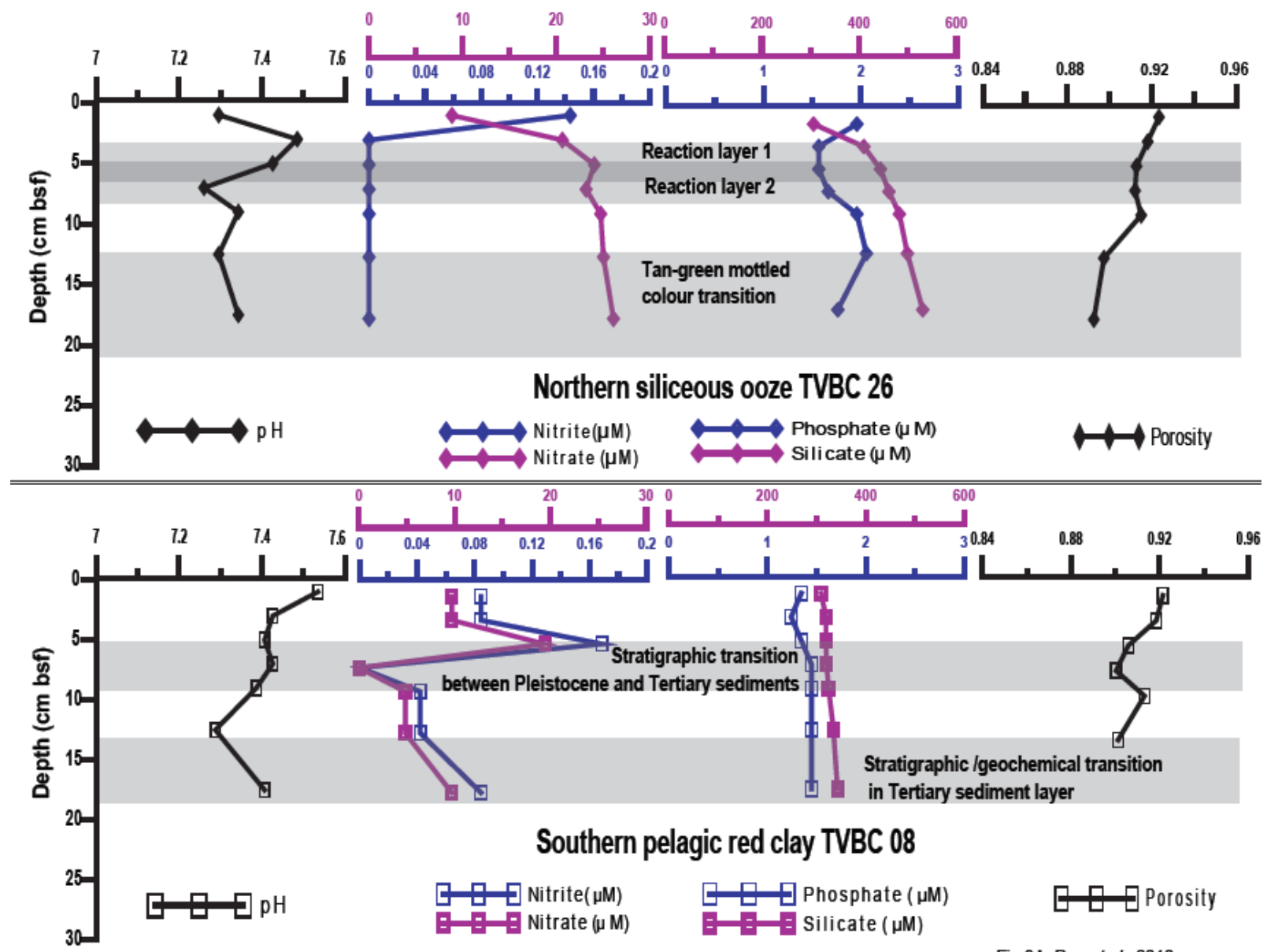

Fig 3A Das ef al., 2010 


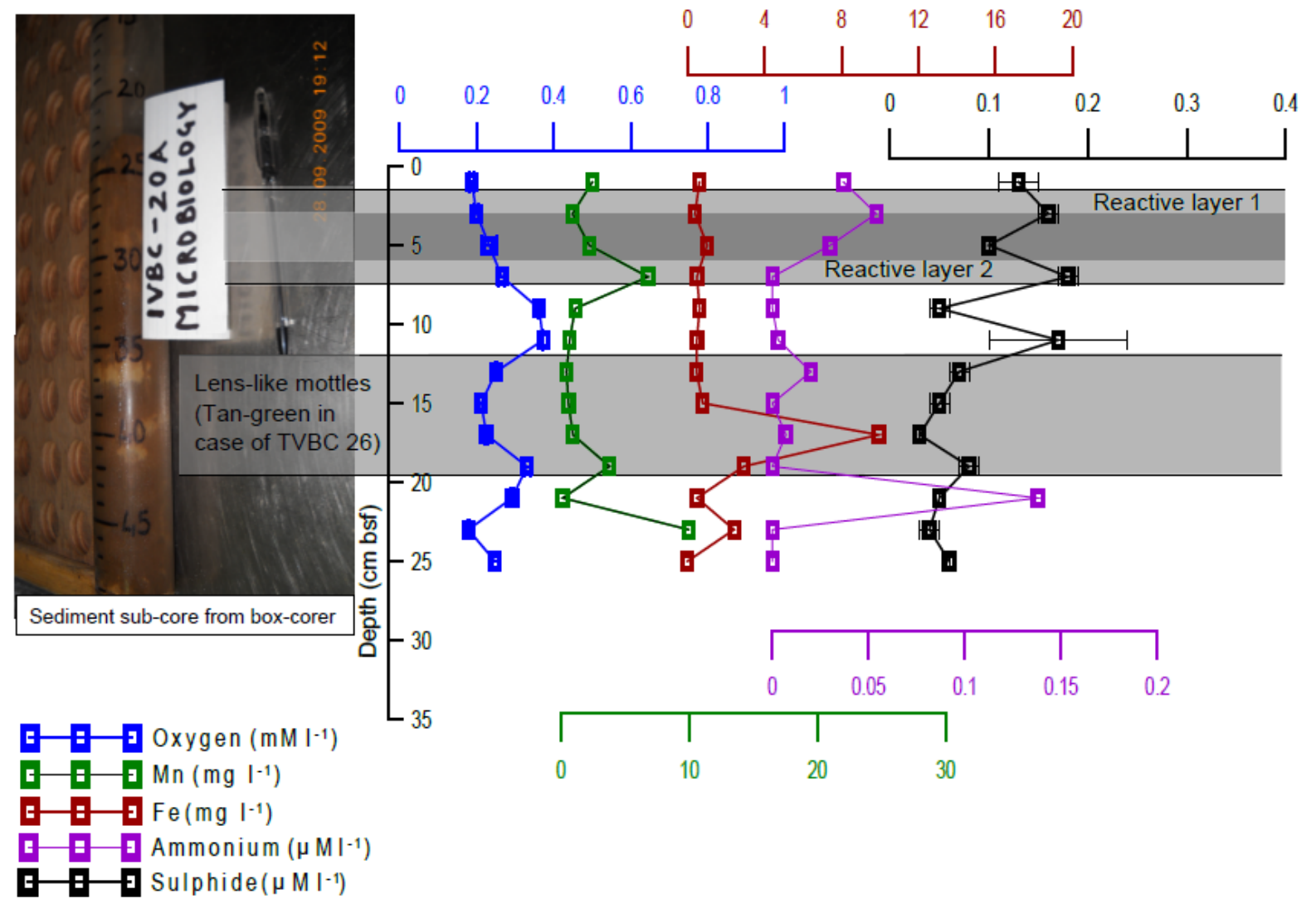

Fig 3B. Das et al.,2010 

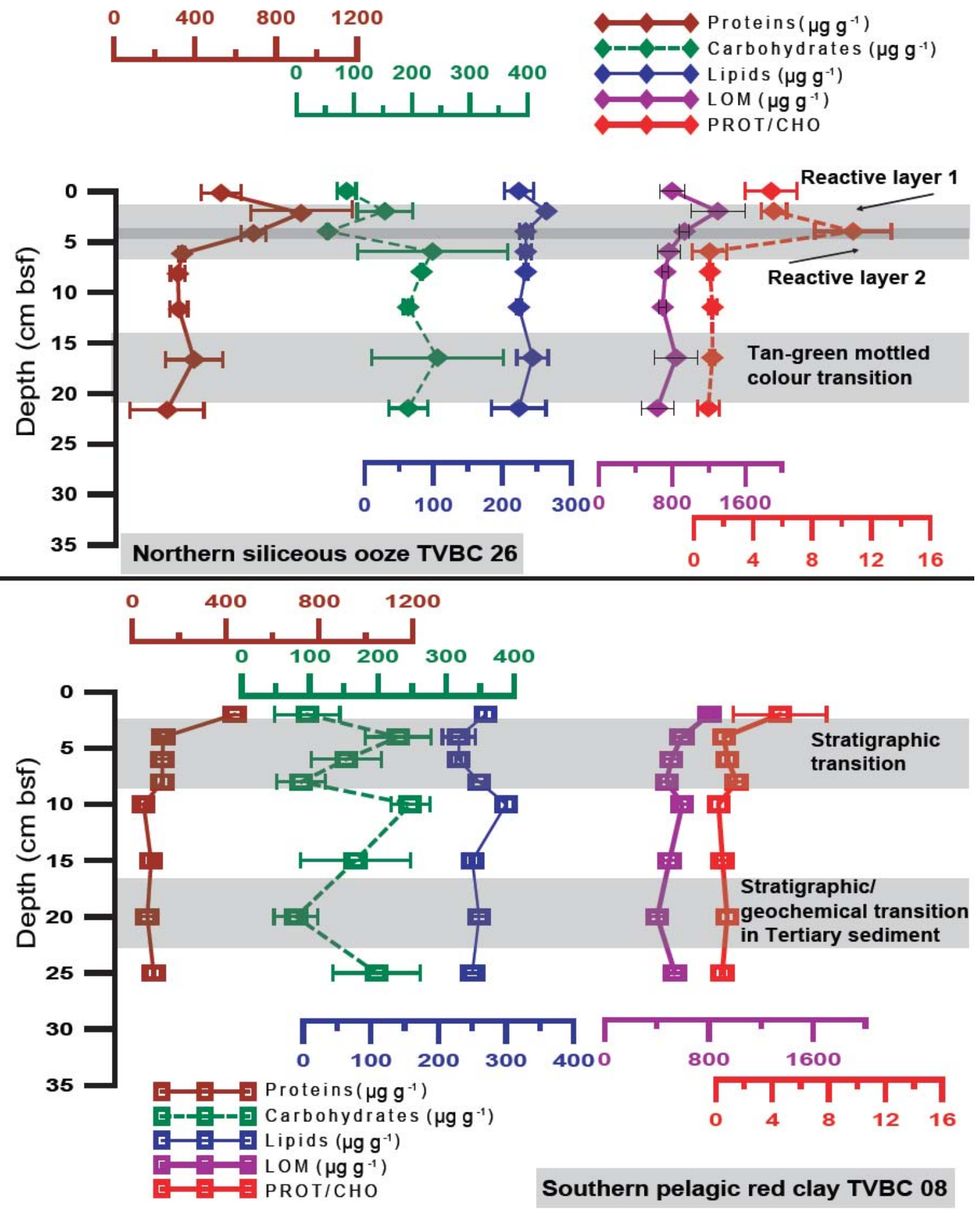

Fig. 4. Das et al., 2010 

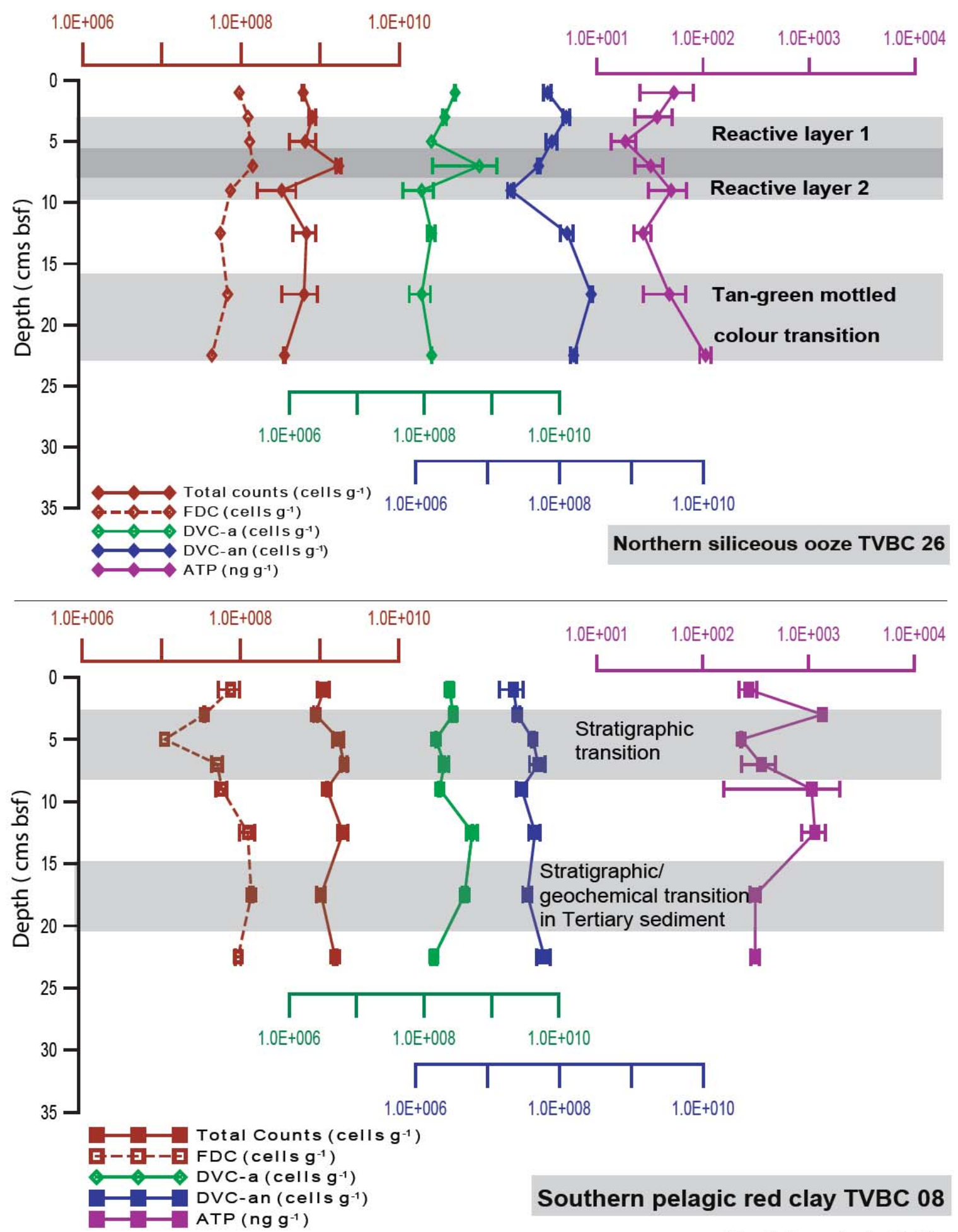

Fig. 5 Das et al., 2010 


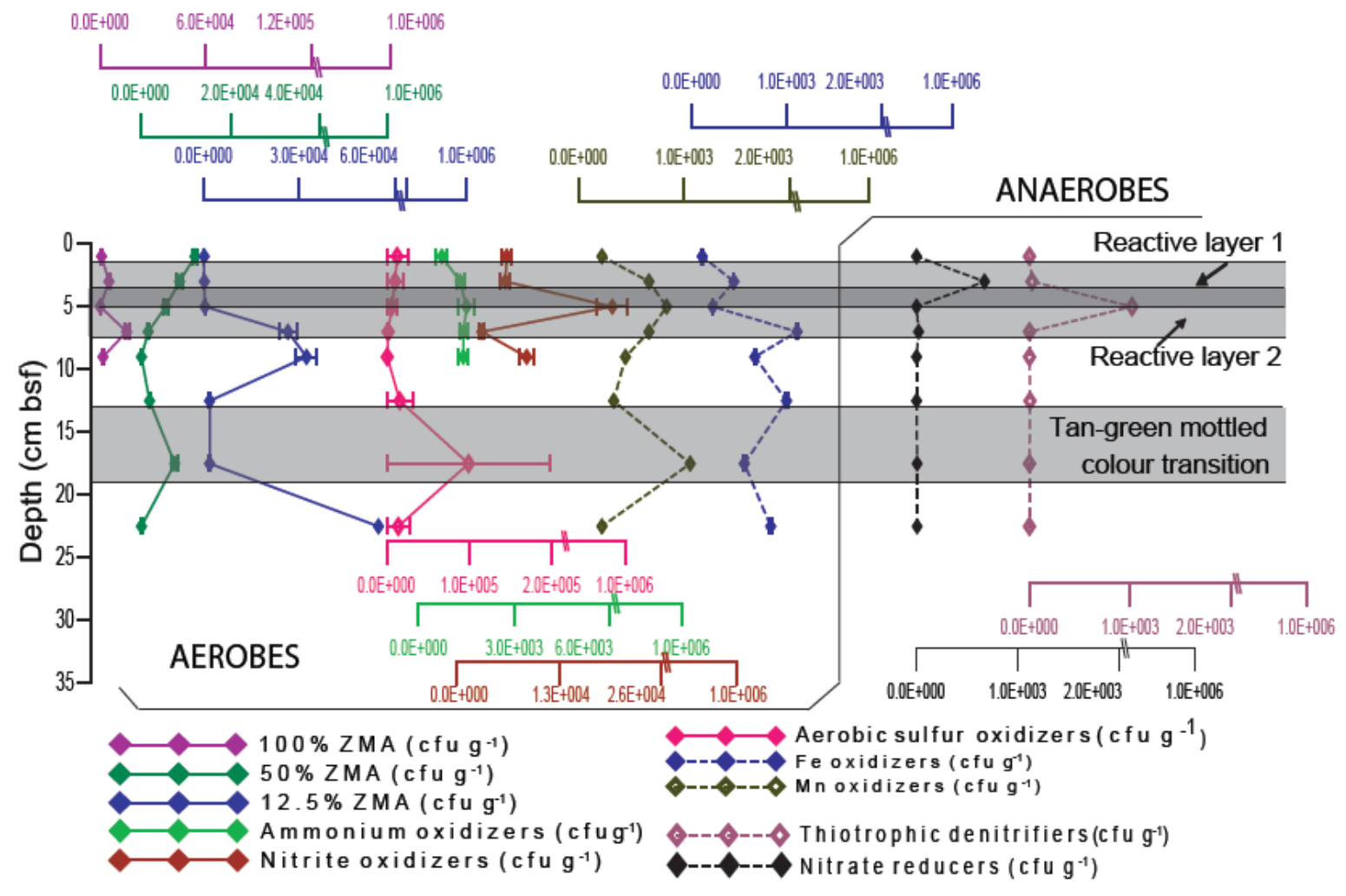

Northern siliceous ooze TVBC 26

Fig. 6A Das et al., 2010 


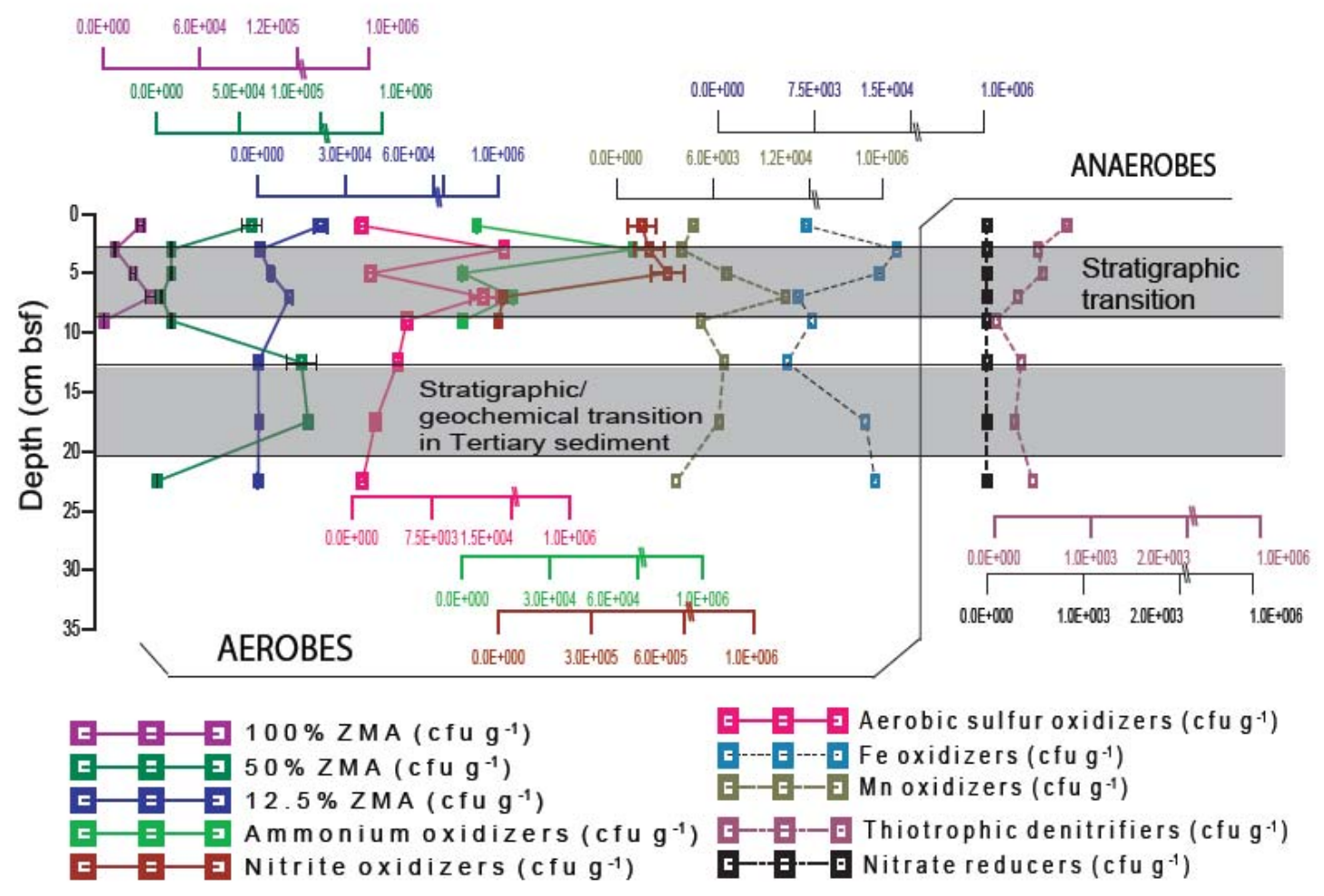

Southern pelagic red clay TVBC 08

Fig. 6B Das et al., 2010 


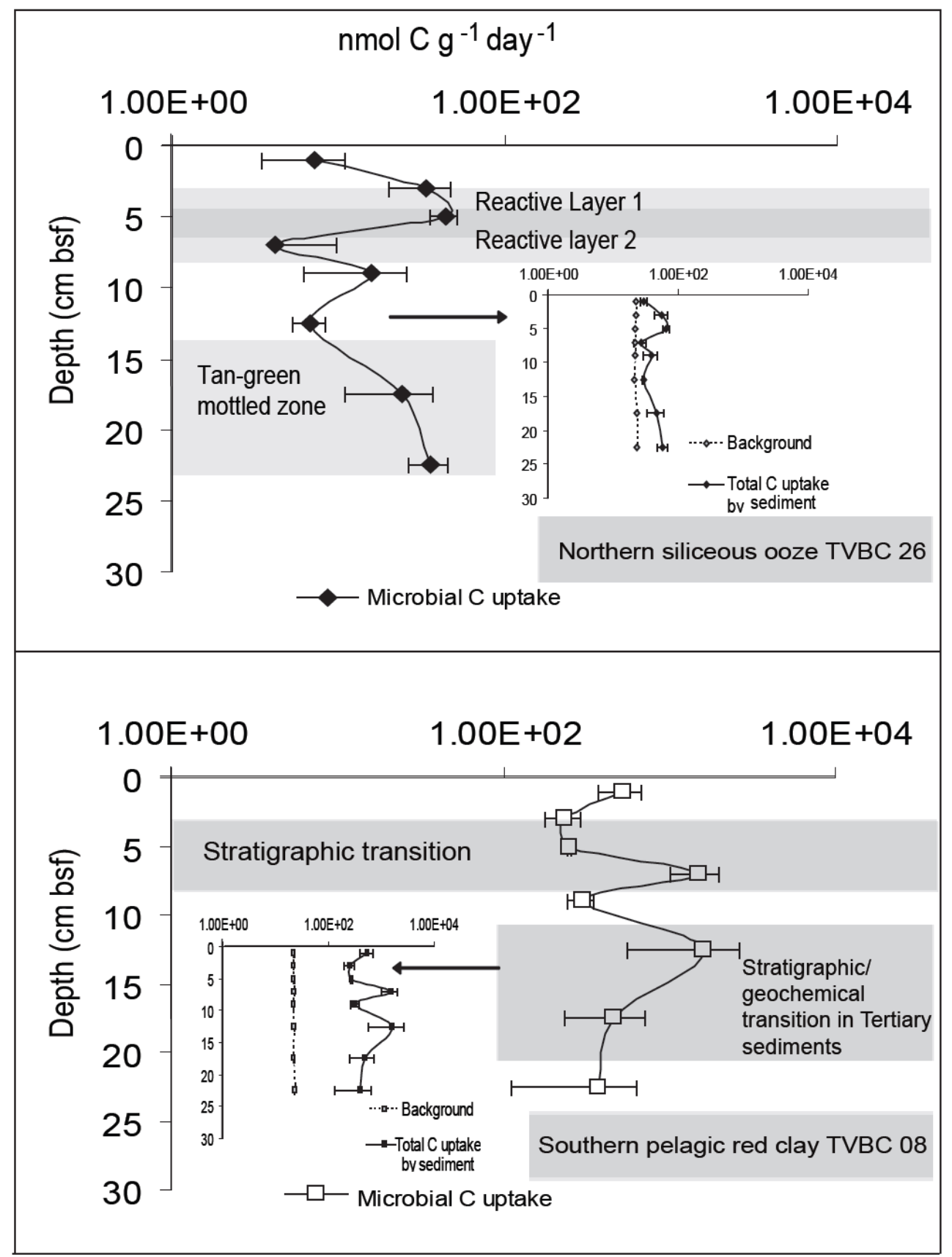

Fig. 7. Das et al., 2010 


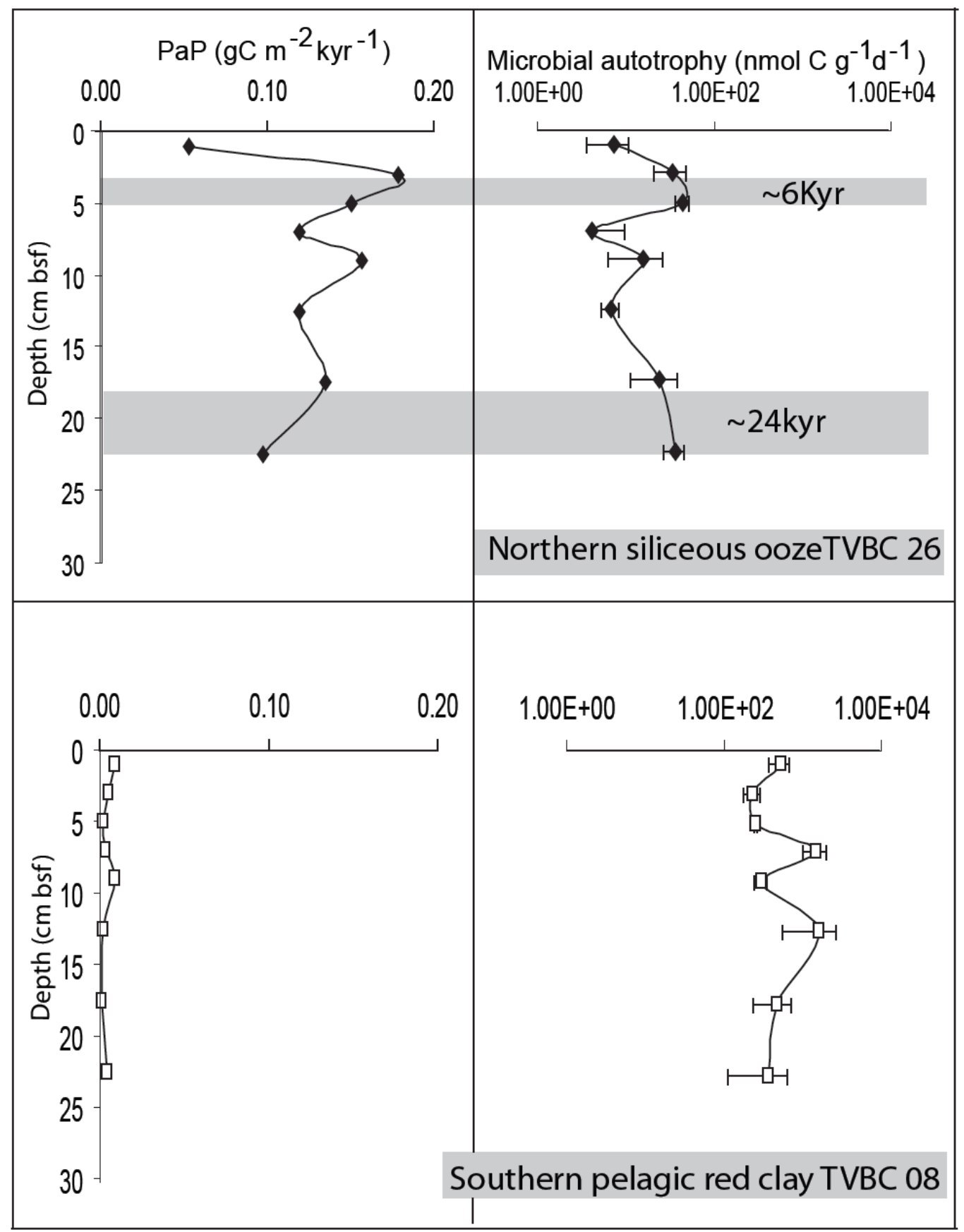

Fig. 8. Das et al., 2010 
Northern siliceous ooze TVBC 26

A Simulation A1 Towards nitrate reduction/ denitrification
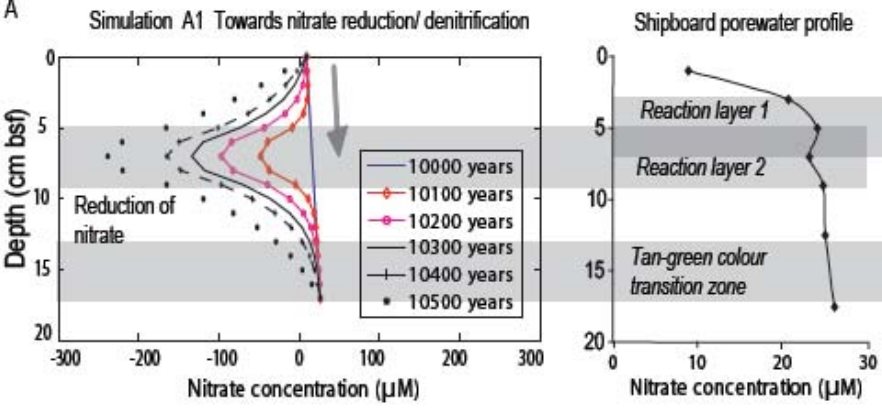

Simulation A2 Towards nitrification

B
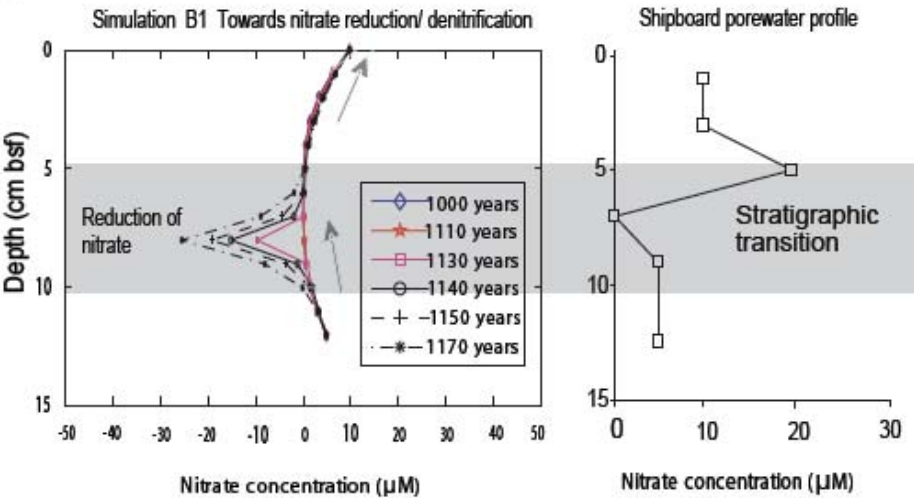

Southern pelagic red clay TVBC 08

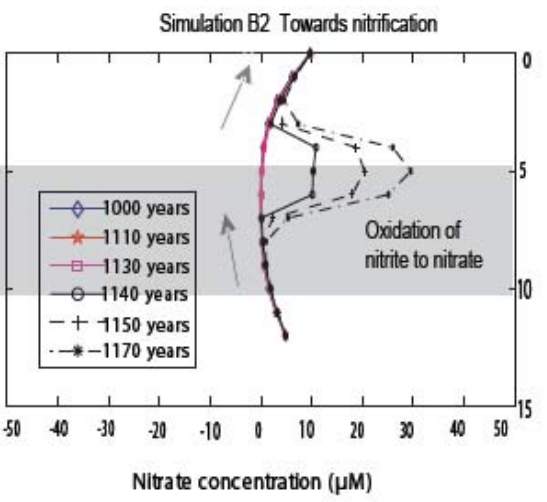

Fig 9 Das et al., 2010 
Table 1. Comparison of ATP values of other established vent fields to CIB stations.

$\begin{array}{llll}\text { Location } & \text { Type } & \text { Range of ATP }\left(\mathrm{ng} \mathrm{g}^{-1}\right) & \text { Reference } \\ 21^{\circ} \mathrm{N} \text { EPR } & \text { Particulate matter, black smoker } & 71-125 & \text { Karl et al, } 1989 \\ \text { Guaymas Basin } & \text { Sediments } & 68-1005 & \text { Haberstroh and Karl, } 1989 \\ & \text { Control deep-sediments } & 100-200 & \text { Haberstroh and Karl, } 1989 \\ \text { TVBC-26, } 10^{\circ} \mathrm{S}, 75^{\circ} 30^{\prime} \mathrm{E} & \text { Sediments } & 18-106 & \text { Present work } \\ & \text { (northern, TOC-rich) } & & \text { Present work } \\ \text { TVBC-08, } 16^{\circ} \mathrm{S}, 75^{\circ} 30^{\prime} \mathrm{E} & \text { Sediments } & 232-1354 & \end{array}$


Table 2. Comparison of ${ }^{14} \mathrm{C}$ incorporation values of CIB stations to other established vent fields.

\begin{tabular}{|c|c|c|c|c|}
\hline Location & Type & ${ }^{14} C$ incorporation $*$ & Condition & Reference \\
\hline $21^{\circ} \mathrm{N}, \mathrm{EPR}$ & Water, White smoker & 12.7 & $1 \mathrm{~atm}, 3^{\circ} \mathrm{C}, 24 \mathrm{~h}$, dark & Wirsen et al., 1986 \\
\hline Juan de Fuca & Water & 201.7 & $1 \mathrm{~atm}$, dark & Chase et al., 1985 \\
\hline Guaymas Basin & Bacterial mats & 444000 & 1 atm,dark, $28^{\circ} \mathrm{C}$ & Nelson et al., 1989 \\
\hline Guaymas Basin & Bacterial Mats & 12000 & $1 \mathrm{~atm}$, dark, $8^{\circ} \mathrm{C}$ & Nelson et al., 1989 \\
\hline TVBC-26 & Sediments & $5-45$ & 1atm, dark, $5^{\circ} \mathrm{C}$ & Present work \\
\hline TVBC-08 & Sediments & $230-1600$ & 1atm, dark, $5^{\circ} \mathrm{C}$ & Present work \\
\hline
\end{tabular}

